Article

\title{
Synthesis and Characterisation of Lanthanide $N$-Trimethylsilyl and -Mesityl Functionalised Bis(iminophosphorano)methanides and -Methanediides
}

\author{
George Marshall, Ashley J. Wooles, David P. Mills, William Lewis, Alexander J. Blake and \\ Stephen T. Liddle *
}

School of Chemistry, University of Nottingham, University Park, Nottingham, NG7 2RD, UK; E-Mails: pcxgm4@nottingham.ac.uk (G.M.); ashley.wooles@nottingham.ac.uk (A.J.W.); david.mills@manchester.ac.uk (D.P.M.); pczwl@exmail.nottingham.ac.uk (W.L.);

a.j.blake@nottingham.ac.uk (A.J.B.)

* Author to whom correspondence should be addressed; E-Mail: stephen.liddle@nottingham.ac.uk; Tel.: +44-115-846-7167 (ext. 67167); Fax: +44-115-951-3563.

Received: 8 November 2013; in revised form: 4 December 2013 / Accepted: 5 December 2013 / Published: 12 December 2013

Abstract: We report the extension of the series of $\left\{\mathrm{BIPM}^{\mathrm{TMS}} \mathrm{H}\right\}^{-}\left(\mathrm{BIPM}^{\mathrm{R}}=\mathrm{C}\left\{\mathrm{PPh}_{2} \mathrm{NR}\right\}_{2}\right.$, TMS = trimethylsilyl) derived rare earth methanides by the preparation of $\left[\mathrm{Ln}\left(\mathrm{BIPM}^{\mathrm{TMS}} \mathrm{H}\right)(\mathrm{I})_{2}(\mathrm{THF})\right](\mathrm{Ln}=\mathrm{Nd}, \mathrm{Gd}, \mathrm{Tb}), \mathbf{1 a}-\mathbf{c}$, in $34-50 \%$ crystalline yields via the reaction of $\left[\operatorname{Ln}(\mathrm{I})_{3}(\mathrm{THF})_{3.5}\right]$ with $\left[\mathrm{Cs}\left(\mathrm{BIPM}^{\mathrm{TMS}} \mathrm{H}\right)\right]$. Similarly, we have extended the range of $\left\{\mathrm{BIPM}^{\mathrm{Mes}} \mathrm{H}\right\}^{-}(\mathrm{Mes}=2,4,6$-trimethylphenyl) derived rare earth methanides with the preparation of $\left[\mathrm{Gd}\left(\mathrm{BIPM}^{\mathrm{Mes}} \mathrm{H}\right)(\mathrm{I})_{2}(\mathrm{THF})_{2}\right], \quad 3,(49 \%)$ and $\left[\mathrm{Yb}\left(\mathrm{BIPM}^{\mathrm{Mes}} \mathrm{H}\right)(\mathrm{I})_{2}(\mathrm{THF})\right]$, 4, $(26 \%)$, via the reaction of $\left[\mathrm{Ln}(\mathrm{I})_{3}(\mathrm{THF})_{3.5}\right]$ with $\left[\left\{\mathrm{K}\left(\mathrm{BIPM}^{\mathrm{Mes}} \mathrm{H}\right)\right\}_{2}\right]$. Attempts to prepare dysprosium and erbium analogues of $\mathbf{3}$ or $\mathbf{4}$ were not successful, with the ion pair species $\left[\operatorname{Ln}\left(\mathrm{BIPM}^{\mathrm{Mes}} \mathrm{H}\right)_{2}\right]\left[\mathrm{BIPM}^{\mathrm{Mes}} \mathrm{H}\right](\mathrm{Ln}=\mathrm{Dy}, \mathrm{Er}), \mathbf{5 a}-\mathbf{b}$, isolated in $31-39 \%$ yield. The TMEDA $\left(N^{\prime}, N^{\prime}, N^{\prime \prime}, N^{\prime \prime}\right.$-tetramethylethylenediamine) adducts $\left[\operatorname{Ln}\left(\mathrm{BIPM}^{\mathrm{Mes}} \mathrm{H}\right)(\mathrm{I})_{2}(\mathrm{TMEDA})\right]$ $(\mathrm{Ln}=\mathrm{La}, \mathrm{Gd}), \mathbf{6} \mathbf{a}-\mathbf{b}$, were prepared in quantitative yield via the dissolution of $\left[\mathrm{La}\left(\mathrm{BIPM}^{\mathrm{Mes}} \mathrm{H}\right)(\mathrm{I})_{2}(\mathrm{THF})\right]$ or $\mathbf{3}$ in a TMEDA/THF solution. The reactions of $\left[\operatorname{Ln}\left(\mathrm{BIPM}^{\mathrm{Mes}} \mathrm{H}\right)(\mathrm{I})_{2}(\mathrm{THF})\right][\mathrm{Ln}=\mathrm{La}, \mathrm{Ce}, \mathrm{Pr}$, and $\mathrm{Gd}(\mathbf{3})]$ or $\mathbf{6 a}-\mathbf{b}$ with a selection of bases did not afford $\left[\mathrm{La}\left(\mathrm{BIPM}^{\mathrm{Mes}}\right)(\mathrm{I})(\mathrm{S})_{n}\right](\mathrm{S}=$ solvent) as predicted, but instead led to the isolation of the heteroleptic complexes $\left[\mathrm{Ln}\left(\mathrm{BIPM}^{\mathrm{Mes}}\right)\left(\mathrm{BIPM}^{\mathrm{Mes}} \mathrm{H}\right)\right](\mathrm{Ln}=\mathrm{La}, \mathrm{Ce}, \mathrm{Pr}$ and $\mathrm{Gd})$, 7a-d, in low yields due to ligand scrambling. 
Keywords: lanthanide; methanide; methanediide

\section{Introduction}

Since Cavell et al. reported the first rare earth bis(iminophosphorano)methanediide complex, namely $\left[\mathrm{Sm}\left(\mathrm{BIPM}^{\mathrm{TMS}}\right)\left(\mathrm{NCy}_{2}\right)(\mathrm{THF})\right]\left(\mathrm{BIPM}^{\mathrm{TMS}}=\left\{\mathrm{C}\left(\mathrm{PPh}_{2} \mathrm{NSiMe}_{3}\right)_{2}\right\}^{2-}\right)[1]$, a wide range of $\mathrm{BIPM}^{\mathrm{R}}$ - derived rare earth complexes have been reported with the $\mathrm{BIPM}^{\mathrm{R}}$ ligand being either mono-deprotonated $\left(\left\{B I P M^{R} H\right\}^{-}\right)$and coordinating as a methanide, or doubly deprotonated $\left(\left\{\mathrm{BIPM}^{\mathrm{R}}\right\}^{{ }^{2-}}\right)$ and coordinating as either a methanediide or carbene [2-4]. These complexes have shown extensive utility in a range of areas, including hydroamination/cyclisation, hydrosilylation and polymerisation reactions $[5,6]$, and our work towards: (a) the preparation of rare earth heterobimetallics [7]; (b) unusual reactivity towards small molecules [8-10]; and (c) the stabilisation of the Ce(IV) oxidation state [11]. In our studies we have employed primarily the $\mathrm{BIPM}^{\mathrm{TMS}}$ and $\mathrm{BIPM}^{\mathrm{Mes}}\left(\left\{\mathrm{C}\left(\mathrm{PPh}_{2} \mathrm{NMes}_{2}\right\}^{2-} ;\right.\right.$ Mes $=2,4,6-$ trimethylphenyl) ligand frameworks [7,12-16], however, during our studies we have encountered several synthetic limitations in our attempts to prepare $B I P M^{\mathrm{R}}$-derived rare earth complexes for the complete rare earth series. We have employed both alkane elimination and salt metathesis strategies towards the preparation of methanediide complexes of the general formula $\left[\mathrm{Ln}\left(\mathrm{BIPM}^{\mathrm{R}}\right)(\mathrm{X})(\mathrm{THF})_{n}\right]$ $\left(\mathrm{R}=\mathrm{TMS}\right.$ or Mes; $\mathrm{X}=\mathrm{I}, \mathrm{CH}_{2} \mathrm{SiMe}_{3}$ or $\mathrm{CH}_{2} \mathrm{Ph}$ ), with each approach having advantages and limitations.

The reaction of a range of rare earth tri-benzyl complexes $\left[\mathrm{Ln}\left(\mathrm{CH}_{2} \mathrm{Ph}\right)_{3}(\mathrm{THF})_{3}\right](\mathrm{Ln}=\mathrm{La}, \mathrm{Ce}, \mathrm{Pr}$,

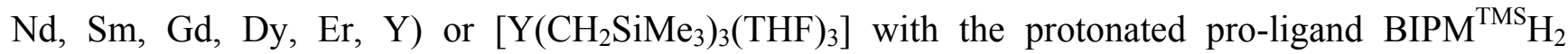
afforded different products depending on the size of the rare earth centre [16-18]. In the case of the smaller rare earths, the methanediide alkyl complexes $\left[\mathrm{Ln}\left(\mathrm{BIPM}^{\mathrm{TMS}}\right)(\mathrm{R})(\mathrm{THF})\right]\left(\mathrm{R}=\mathrm{CH}_{2} \mathrm{Ph}: \mathrm{Ln}=\mathrm{Dy}\right.$, $\mathrm{Er}, \mathrm{Y} ; \mathrm{R}=\mathrm{CH}_{2} \mathrm{SiMe}_{3}$ : $\mathrm{Ln}=\mathrm{Y}$ ) were isolated [16-18], however for the larger rare earths the only isolable products were the bis-BIPM complexes $\left[\mathrm{Ln}\left(\mathrm{BIPM}^{\mathrm{TMS}}\right)\left(\mathrm{BIPM}^{\mathrm{TMS}} \mathrm{H}\right)\right](\mathrm{Ln}=\mathrm{La}, \mathrm{Ce}, \mathrm{Pr}, \mathrm{Nd}$, $\mathrm{Sm}, \mathrm{Gd}$ ) [16]. This variation in reactivity was ascribed to the lanthanide contraction [19], with ligand scrambling occurring in the attempted preparations of the larger rare earth analogues despite the high steric demands of the BIPM ${ }^{\mathrm{TMS}}$ ligand [16]. By a similar methodology we prepared [Ln(BIPM $\left.{ }^{\mathrm{TMS}}\right)(\mathrm{I})(\mathrm{THF})_{2}$ ] $(\mathrm{Ln}=\mathrm{Y}, \mathrm{Er})$ via the reaction of $\left[\mathrm{Ln}\left(\mathrm{CH}_{2} \mathrm{Ph}\right)_{2}(\mathrm{I})(\mathrm{THF})_{3}\right]$ with $\mathrm{BIPM}^{\mathrm{TMS}} \mathrm{H}_{2}$ [15], but unfortunately this methodology could not be applied across the rare earth series due to the inaccessibility of $\left[\mathrm{Ln}\left(\mathrm{CH}_{2} \mathrm{Ph}\right)_{2}(\mathrm{I})(\mathrm{THF})_{3}\right]$ for rare earths larger than erbium [12].

Salt metathesis strategies were first employed in the preparation of [Y(BIPM $\left.\left.{ }^{\mathrm{TMS}} \mathrm{H}\right)(\mathrm{I})_{2}(\mathrm{THF})\right]$, which was isolated in $64 \%$ yield via the reaction of $\left[\left\{\mathrm{K}\left(\mathrm{BIPM}^{\mathrm{TMS}} \mathrm{H}\right)\right\}_{2}\right]$ with $\left[\mathrm{Y}(\mathrm{I})_{3}(\mathrm{THF})_{3.5}\right]$ in refluxing THF over 4 hours [7]. Fine-tuning of the reaction conditions was required with excessive reaction times leading to decomposition. Perhaps surprisingly, applying a similar strategy to La with the reaction of $\left[\mathrm{La}(\mathrm{I})_{3}(\mathrm{THF})_{4}\right]$ and $\left.\left[\left\{\mathrm{K}_{(\mathrm{BIPM}}{ }^{\mathrm{TMS}} \mathrm{H}\right)\right\}_{2}\right]$ does not afford $\left[\mathrm{La}\left(\mathrm{BIPM}^{\mathrm{TMS}} \mathrm{H}\right)(\mathrm{I})_{2}(\mathrm{THF})\right]$ as expected; no reaction is observed at ambient temperature and decomposition is observed at elevated temperatures [12]. Gratifyingly, however, the reaction of $\left[\mathrm{Ln}(\mathrm{I})_{3}(\mathrm{THF})_{4}\right](\mathrm{Ln}=\mathrm{La}$, Ce) with $\left[\mathrm{Rb}\left(\mathrm{BIPM}^{\mathrm{TMS}} \mathrm{H}\right)(\mathrm{THF})_{n}\right]$ affords $\left[\mathrm{Ln}\left(\mathrm{BIPM}^{\mathrm{TMS}} \mathrm{H}\right)(\mathrm{I})_{2}(\mathrm{THF})\right](\mathrm{Ln}=\mathrm{La}, \mathrm{Ce})$ in high yield with no forcing conditions required $[11,13]$. This variation exemplifies the importance of selecting the correct synthetic reagent for the reaction in hand. The reaction of $\left[\operatorname{Ln}\left(\mathrm{BIPM}^{\mathrm{TMS}} \mathrm{H}\right)(\mathrm{I})_{2}(\mathrm{THF})\right](\mathrm{Ln}=\mathrm{Ce}, \mathrm{Y})$ 
with $[\mathrm{K}(\mathrm{Bn})]$ affords the rare earth carbene complexes $\left[\operatorname{Ln}\left(\mathrm{BIPM}^{\mathrm{TMS}}\right)(\mathrm{I})(\mathrm{S})_{n}\right](\operatorname{Ln}=\mathrm{Y}, \mathrm{S}=\mathrm{THF}, n=2$; $\mathrm{Ln}=\mathrm{Ce}, \mathrm{S}=1,2$-dimethoxyethane, $n=1)$ in good yield [7,11].

To fully investigate the importance of the steric demands of the $N-\mathrm{SiMe}_{3}$ group in BIPM ${ }^{\mathrm{TMS}}$, we employed a different BIPM ligand, namely the $N$-aryl substituted BIPM ${ }^{\text {Mes }}$ system. In contrast to the difficulties experienced when employing salt metathesis strategies with the BIPM ${ }^{\mathrm{TMS}}$ framework, we previously prepared $\left[\mathrm{Ln}\left(\mathrm{BIPM}^{\mathrm{Mes}} \mathrm{H}\right)(\mathrm{I})_{2}(\mathrm{THF})_{2}\right](\mathrm{Ln}=\mathrm{La}, \mathrm{Ce}, \mathrm{Pr}, \mathrm{Nd}, \mathrm{Sm})$ via the straight-forward reaction of $\left[\mathrm{Ln}(\mathrm{I})_{3}(\mathrm{THF})_{n}\right]$ with $\left.\left[\left\{\mathrm{K}_{(\mathrm{BIPM}}{ }^{\mathrm{Mes}} \mathrm{H}\right)\right\}_{2}\right][12,14]$. Similarly to the $\mathrm{BIPM}^{\mathrm{TMS}}$ system $\left[\mathrm{La}\left(\mathrm{BIPM}^{\mathrm{Mes}} \mathrm{H}\right)(\mathrm{I})_{2}(\mathrm{THF})_{2}\right]$ was converted to the rare earth carbene complex [La(BIPM $\left.\left.{ }^{\mathrm{Mes}}\right)(\mathrm{I})(\mathrm{THF})_{3}\right]$ in $53 \%$ yield via reaction with $[\mathrm{K}(\mathrm{Bn})][12]$.

Whilst a range of complexes of the formula $\left[\left\{\operatorname{Ln}\left(\mathrm{BIPM}^{\mathrm{TMS}} \mathrm{H}\right)(\mathrm{Cl})(\mu-\mathrm{Cl})\right\}_{2}\right]$ have been reported previously by the reaction of $\left[\mathrm{Ln}(\mathrm{Cl})_{3}\right]$ and $\left[\left\{\mathrm{K}\left(\mathrm{BIPM}{ }^{\mathrm{TMS}} \mathrm{H}\right)\right\}_{2}\right]$ [20], we have solely utilised iodide precursors. This is to reduce the likelihood of salt occlusion occurring as KI, RbI and CsI have a much lower propensity for salt occlusion in comparison to $\mathrm{LiCl}$ or $\mathrm{KCl}$, and as salt occlusion can often negatively affect reactivity and promote unwanted side reactions this is a major advantage of utilising $\left[\mathrm{Ln}(\mathrm{I})_{3}(\mathrm{THF})_{n}\right]$ precursors. As ligand scrambling and Schlenk-type equilibra proved problematic in alkane elimination strategies, we focused on salt metathesis strategies in our attempts to complete the range of rare earth $\mathrm{BIPM}^{\mathrm{R}} \mathrm{H}(\mathrm{R}=\mathrm{TMS}$, Mes) complexes of the general formula $\left[\mathrm{Ln}\left(\mathrm{BIPM}^{\mathrm{R}} \mathrm{H}\right)(\mathrm{I})_{2}(\mathrm{THF})_{n}\right]$. These complexes would provide an insight into the structure and bonding of rare earth complexes as well as having utility in the preparation of methanediide complexes of the general formula $\left[\mathrm{Ln}\left(\mathrm{BIPM}^{\mathrm{R}}\right)(\mathrm{I})(\mathrm{THF})_{n}\right]$. With these complexes in hand we would be able to investigate what, if any, effect the varying metal size would have on their structure and reactivity.

\section{Results and Discussion}

As rare earth ions are predominantly paramagnetic, any NMR spectroscopic studies performed are often difficult to interpret, which makes it problematic to both follow reaction progress and to identify the products of reactions. For this reason single crystal X-ray diffraction studies are essential to unambiguously identify the outcome of reactions involving paramagnetic rare earth metals. Unfortunately, we often observe that some complexes do not crystallise readily, despite repeated attempts, one reason for which may be that they do not possess an optimal metal/ligand size ratio for crystal growth [21]. For this reason we commonly employ a range of rare earths of varying sizes, Table 1, in our studies to ensure we have the best chance at fully identifying the products of reactions. Due to the difficulties in identifying reaction products without X-ray diffraction studies, we have only included structurally authenticated complexes in this report. 
Table 1. Six-coordinate ionic radii and covalent radii (Å) of Ln(III) complexes [22,23].

\begin{tabular}{cccccc}
\hline Metal & Ionic radius & Covalent radius & Metal & Ionic radius & Covalent radius \\
\hline $\mathrm{Sc}$ & 0.745 & 1.70 & $\mathrm{Gd}$ & 0.938 & 1.96 \\
$\mathrm{Y}$ & 0.900 & 1.90 & $\mathrm{~Tb}$ & 0.923 & 1.94 \\
$\mathrm{La}$ & 1.032 & 2.07 & $\mathrm{Dy}$ & 0.912 & 1.92 \\
$\mathrm{Ce}$ & 1.01 & 2.04 & $\mathrm{Ho}$ & 0.901 & 1.92 \\
$\mathrm{Pr}$ & 0.99 & 2.03 & $\mathrm{Er}$ & 0.890 & 1.89 \\
$\mathrm{Nd}$ & 0.983 & 2.01 & $\mathrm{Tm}$ & $\mathrm{N} / \mathrm{A}$ & 1.90 \\
$\mathrm{Pm}$ & $\mathrm{N} / \mathrm{A}$ & 1.99 & $\mathrm{Yb}$ & 0.868 & 1.87 \\
$\mathrm{Sm}$ & 0.958 & 1.98 & $\mathrm{Lu}$ & 0.861 & 1.87 \\
$\mathrm{Eu}$ & 0.947 & 1.98 & & & \\
\hline
\end{tabular}

\subsection{Preparation of BIPM ${ }^{T M S} H$ Rare Earth Methanides}

As previously discussed, we have reported the preparation of $\left[\mathrm{Ln}\left(\mathrm{BIPM}^{\mathrm{TMS}} \mathrm{H}\right)(\mathrm{I})_{2}(\mathrm{THF})\right](\mathrm{Ln}=\mathrm{La}$, $\mathrm{Ce})$ in high yields $\left(77 \%\right.$ and $89 \%$, respectively) via the reaction of $\left[\operatorname{Ln}(\mathrm{I})_{3}(\mathrm{THF})_{4}\right]$ with the heavy group 1 ligand transfer reagent $\left[\mathrm{Rb}\left(\mathrm{BIPM}^{\mathrm{TMS}} \mathrm{H}\right)(\mathrm{THF})_{n}\right]$ under ambient conditions $[11,13]$. As this strategy was successful for the two largest rare earth metals (see Table 1), we extended this methodology across the rare earth series using the cesium ligand transfer reagent to maximise our chances of success. The reactions of $\left.\left[\mathrm{Ln}(\mathrm{I})_{3}(\mathrm{THF})_{3.5}\right)\right](\mathrm{Ln}=\mathrm{Nd}, \mathrm{Gd}, \mathrm{Tb})$ with $\left[\mathrm{Cs}\left(\mathrm{BIPM}{ }^{\mathrm{TMS}} \mathrm{H}\right)\right]$ afforded, following filtration and workup, $\left[\operatorname{Ln}\left(\mathrm{BIPM}^{\mathrm{TMS}} \mathrm{H}\right)(\mathrm{I})_{2}(\mathrm{THF})\right](\mathrm{Ln}=\mathrm{Nd}, \mathbf{1 a}, 37 \%$; $\mathrm{Gd}, \mathbf{1 b}$, $50 \%$; Tb, 1c, 34\%) with concomitant elimination of CsI (Scheme 1). As Nd(III), Gd(III) and Tb(III) are highly paramagnetic, NMR spectroscopic studies were inconclusive, and due to this each complex was crystallised from either THF or toluene to ensure purity of the sample. Unfortunately this also led to lower isolated yields (36-54\%) compared to the diamagnetic La (77\%) or weakly paramagnetic Ce (89\%) analogues which could both be identified by NMR spectroscopy.

Scheme 1. Preparation of 1a-c.

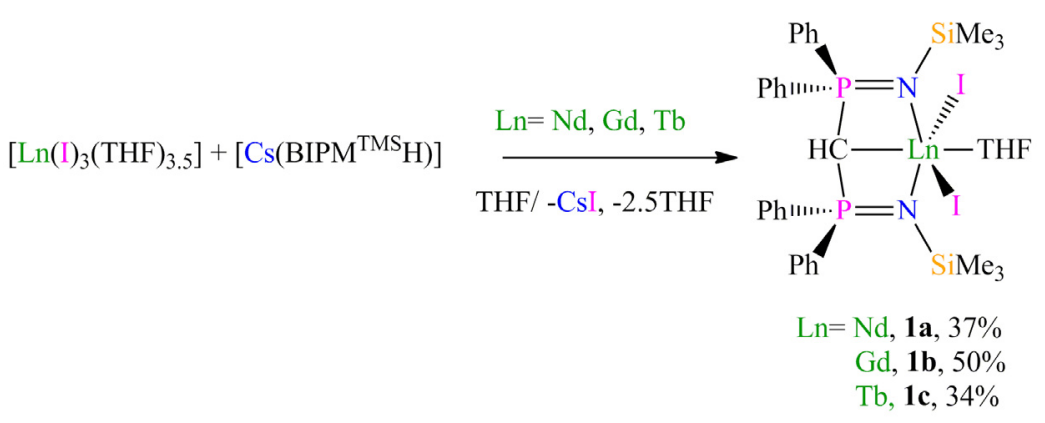

The identities of $1 \mathbf{a}-\mathbf{c}$ were confirmed by single crystal X-ray diffraction studies, elemental analysis and solution magnetic studies (vide infra, Table 2). The solid-state structures of $\mathbf{1 a} \mathrm{C}_{7} \mathrm{H}_{8}$ and $\mathbf{1 c} \mathrm{OC}_{4} \mathrm{H}_{8}$ are shown in Figures 1 and 2, respectively, with selected bond lengths and angles shown in Table S1. Each complex exhibits a distorted octahedral geometry with the metal centre coordinated by tridentate $\left\{\mathrm{BIPM}^{\mathrm{TMS}} \mathrm{H}\right\}^{-}$through the methanide carbon atom and the two imino nitrogens [N-Ln-N angles: 1a, 116.28(14) ${ }^{\circ}$; 1b, 93.6(2) ${ }^{\circ}$; 1c, 93.40(10 $)^{\circ}$ ], two iodide ligands and a THF molecule. Despite exhibiting the same overall structure there is a variation in conformation of the iodides and THF molecules in 
1a-c. Complex 1a is isostructural to $\left[\operatorname{Ln}\left(\mathrm{BIPM}^{\mathrm{TMS}} \mathrm{H}\right)(\mathrm{I})_{2}(\mathrm{THF})\right](\mathrm{Ln}=\mathrm{La}, \mathrm{Ce})[11,13]$, with the coordinated THF molecule being trans to the methanide carbon [O1-Nd1-C1 angle: $151.54(13)^{\circ}$ ] with the two iodides being mutually trans [I1-Nd1-I2 angle: $\left.156.167(13)^{\circ}\right]$. In contrast, $\mathbf{1 b}-\mathbf{c}$ are isostructural to $\left[\operatorname{Ln}\left(\mathrm{BIPM}^{\mathrm{TMS}} \mathrm{H}\right)(\mathrm{I})_{2}(\mathrm{THF})\right](\mathrm{Ln}=\mathrm{Dy}, \mathrm{Y})$ [7,12], and exhibit the THF molecule cis to the methanide carbon rather than trans [O1-Gd1-C1: 86.5(2) ${ }^{\circ}$; O1-Tb1-C1: 87.30(10) ${ }^{\circ}$, with the two iodide ligands being mutually cis [I1-Gd1-I2: 97.20(2) ${ }^{\circ}$ : I1-Tb1-I2: 96.364(9) ${ }^{\circ}$. The variation of conformation may be due to the varying size of the metal centre present as the larger rare earths $\mathrm{La}, \mathrm{Ce}$ and $\mathrm{Nd}$ favour the trans conformation with the smaller rare earths $\mathrm{Gd}, \mathrm{Tb}$, Dy and $\mathrm{Y}$ favouring the cis conformation (for radii see Table 1). However, this could also be due to solvent effects on crystallisation favouring different conformations during crystal packing as $\mathbf{1 a}$ and $\left[\mathrm{Ln}\left(\mathrm{BIPM}^{\mathrm{TMS}} \mathrm{H}\right)(\mathrm{I})_{2}(\mathrm{THF})\right](\mathrm{Ln}=\mathrm{La}, \mathrm{Ce})[11,13]$ were crystallised from toluene and adopt the trans geometry, whereas 1b-c and [ $\left.\mathrm{Ln}\left(\mathrm{BIPM}^{\mathrm{TMS}} \mathrm{H}\right)(\mathrm{I})_{2}(\mathrm{THF})\right](\mathrm{Ln}=\mathrm{Dy}, \mathrm{Y})$ [7,12] were crystallised from THF and adopt the cis conformation. There is a general shortening of the Ln-C, Ln-N, Ln-I and Ln-O bond distances between 1a-1c which is in agreement with the lanthanide contraction (see Table 1) [19], and is consistent with the bond distances reported for $\left[\mathrm{Ln}\left(\mathrm{BIPM}^{\mathrm{TMS}} \mathrm{H}\right)(\mathrm{I})_{2}(\mathrm{THF})\right](\mathrm{Ln}=\mathrm{La}, \mathrm{Ce}, \mathrm{Dy}, \mathrm{Y})$ [7,11-13]. The bond distances about the metal centres in $1 \mathbf{a}-\mathbf{c}$ are all within the range of previously reported bond distances [24], and are unremarkable. The mean endocyclic P-C and P-N bond distances in 1a-c and the previously reported $\left[\mathrm{Ln}\left(\mathrm{BIPM}^{\mathrm{TMS}} \mathrm{H}\right)(\mathrm{I})_{2}(\mathrm{THF})\right](\mathrm{Ln}=\mathrm{La}, \mathrm{Ce}, \mathrm{Dy}, \mathrm{Y})[7,11-13]$, are statistically indistinguishable suggesting the $\left\{\mathrm{BIPM}^{\mathrm{TMS}} \mathrm{H}\right\}^{-}$coordinates to the metal centre in a similar way despite the variation in metal centre.

Figure 1. Molecular structure of 1 a $\mathrm{C}_{7} \mathrm{H}_{8}$ with selected atom labelling. Displacement ellipsoids are drawn at 50\% probability, with lattice solvent and non-methanide hydrogen atoms omitted for clarity.

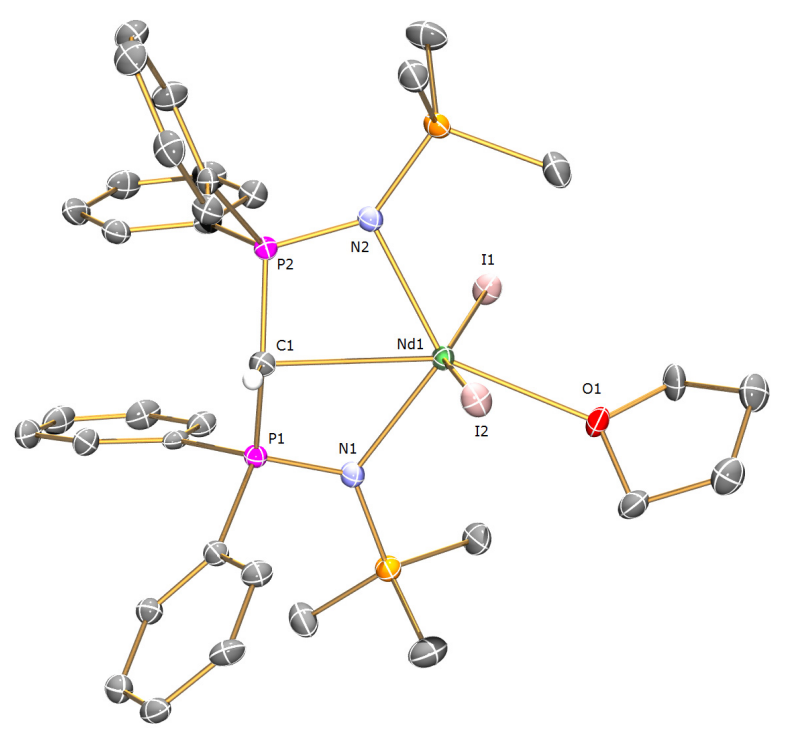


Figure 2. Molecular structure of $1 \mathbf{c} \mathrm{OC}_{4} \mathrm{H}_{8}$ with selected atom labelling. Displacement ellipsoids are drawn at 50\% probability, with disordered components, lattice solvent and non-methanide hydrogen atoms omitted for clarity. The structure of $\mathbf{1 b}$ is very similar.

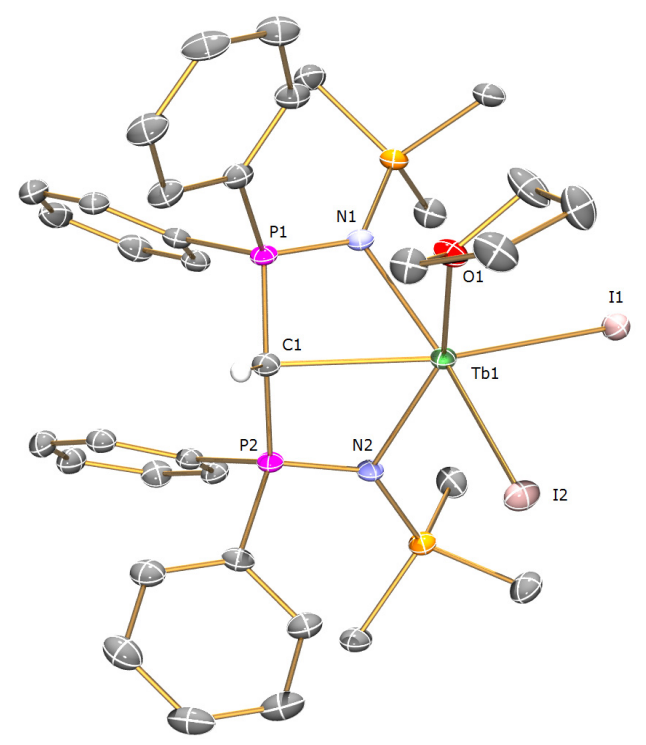

Scheme 2. Preparation of 2.

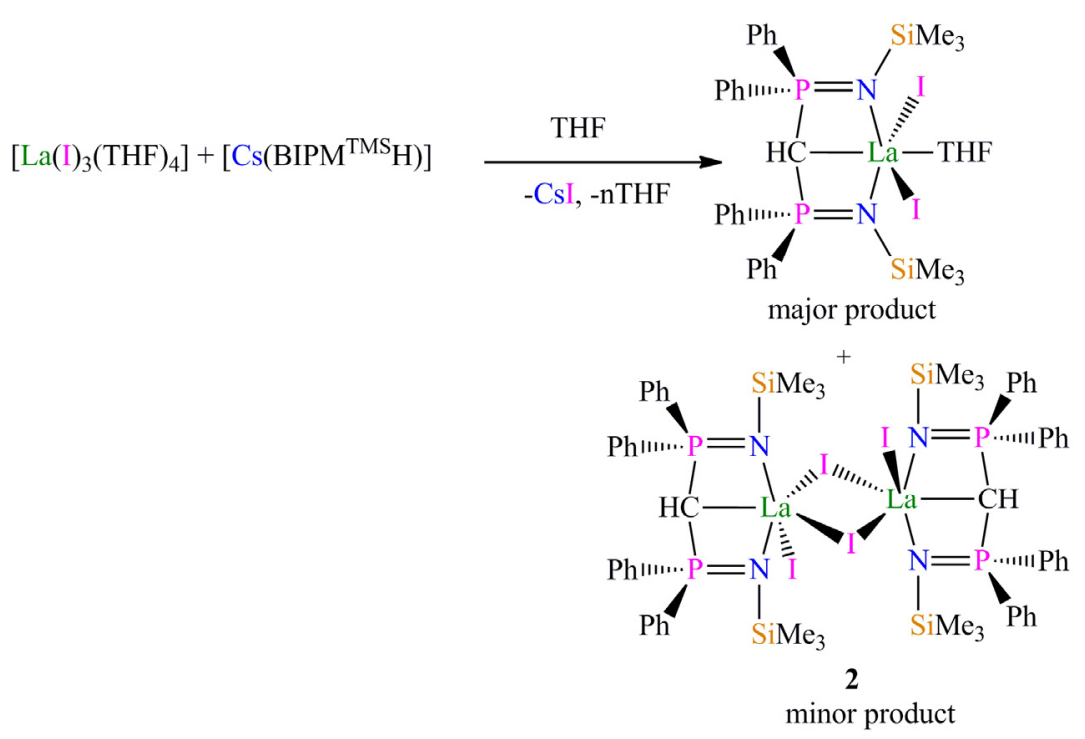

During our studies we have prepared many samples of $\left[\operatorname{Ln}\left(\mathrm{BIPM}^{\mathrm{TMS}} \mathrm{H}\right)(\mathrm{I})_{2}(\mathrm{THF})\right]$ and on one occasion during preparation of $\left[\mathrm{La}\left(\mathrm{BIPM}^{\mathrm{TMS}} \mathrm{H}\right)(\mathrm{I})_{2}\right.$ (THF)] we isolated, from toluene solution, a small crop of colourless crystals which appeared to be of a different morphology to our previously reported $\left[\mathrm{La}\left(\mathrm{BIPM}^{\mathrm{TMS}} \mathrm{H}\right)(\mathrm{I})_{2}(\mathrm{THF})\right]$ [13]. To ensure purity of the sample a single crystal X-ray diffraction study was performed which confirmed its identity as $\left[\left\{\mathrm{La}\left(\mathrm{BIPM}^{\mathrm{TMS}} \mathrm{H}\right)(\mathrm{I})(\mu-\mathrm{I})\right\}_{2}\right], 2{ }_{2} \mathrm{C}_{7} \mathrm{H}_{8}$ (Scheme 2). Complex 2 is dimeric in the solid-state with each lanthanum centre adopting a heavily distorted octahedral geometry and being coordinated by a $\left\{\mathrm{BIPM}^{\mathrm{TMS}} \mathrm{H}\right\}^{-}$in a tridentate fashion [N1-La1-N2 angle: $118.3(2)^{\circ}$, by one terminal iodide and by two iodides that are bridging the two lanthanide centres. The dimeric motif of $\mathbf{2}$ is likely caused by a scarcity of coordinating solvent present during crystallisation with the dimeric form allowing greater saturation of the coordination sphere of the 
lanthanide centres compared to a solvent free monomeric form. Once isolated, 2 has a very low solubility in arene solvents (e.g., $d_{6}$-benzene and $d_{8}$-toluene), which precluded solution NMR spectroscopic studies, while dissolution in more polar solvents to increase solubility (e.g., $d_{8}$-THF) led to solvated monomeric complexes such as $\left[\mathrm{La}\left(\mathrm{BIPM}^{\mathrm{TMS}} \mathrm{H}\right)(\mathrm{I})_{2}\left(d_{8}-\mathrm{THF}\right)\right]$. Although NMR spectroscopy was not conclusive, the identity of $\mathbf{2}$ was confirmed by elemental analysis. The dimeric form of $\mathbf{2}$ is analogous to the chloride congeners reported by Roesky et al., namely $\left[\left\{\operatorname{Ln}\left(\mathrm{BIPM}^{\mathrm{TMS}} \mathrm{H}\right)(\mathrm{Cl})(\mu-\mathrm{Cl})\right\}_{2}\right]$ $(\mathrm{Ln}=\mathrm{Sm}, \mathrm{Dy}, \mathrm{Er}, \mathrm{Yb}, \mathrm{Lu}, \mathrm{Y})$, which despite being prepared in THF solution adopt solvent free dimeric conformations when crystallised from toluene [20].

The solid-state structure of $22 \mathrm{C}_{7} \mathrm{H}_{8}$ is depicted in Figure 3 with selected bond lengths and angles shown in Table S1. There is a variation in La1-I bond distances in 2, with the two bridging iodides being bound asymmetrically, with bond lengths of 3.2253(8) $\AA$ (La1-I2) and 3.3114(6) $\AA$ (La1-I2a), but both are still longer than the La1-I1 distance of 3.1144(7) $\AA$ due to the bridging $v$ s terminal nature of the iodide ligands. Although the mean La1-N distance in 2 [2.443(6) $\AA]$ is statistically indistinguishable to the La1-N distances in $\left[\mathrm{La}\left(\mathrm{BIPM}^{\mathrm{TMS}} \mathrm{H}\right)(\mathrm{I})_{2}(\mathrm{THF})\right]$ (mean: $2.438(6) \AA$ ), there is a large variation in the La1-C1 bond distance, with the La1-C1 distance in 2 [2.778(8) Å] being shorter than the La-C distance in $\left[\mathrm{La}\left(\mathrm{BIPM}^{\mathrm{TMS}} \mathrm{H}\right)(\mathrm{I})_{2}(\mathrm{THF})\right][2.859(8) \AA]$ [13]. This shortening of the La1-C1 bond distance is likely due to the absence of O-donor solvents in $\mathbf{2}$, compared to $\left[\mathrm{La}\left(\mathrm{BIPM}^{\mathrm{TMS}} \mathrm{H}\right)(\mathrm{I})_{2}(\mathrm{THF})\right]$ [13], as, according to the HSAB principle, the hard lanthanum centre is predicted to exhibit a stronger interaction with the oxygen of THF rather than the relatively soft methanide carbon, leading to the longer La-C distance in $\left[\mathrm{La}\left(\mathrm{BIPM}^{\mathrm{TMS}} \mathrm{H}\right)(\mathrm{I})_{2}(\mathrm{THF})\right][13]$.

Despite the change in coordination mode between 2 and $\left[\mathrm{La}\left(\mathrm{BIPM}^{\mathrm{TMS}} \mathrm{H}\right)(\mathrm{I})_{2}(\mathrm{THF})\right]$ the $\left\{\mathrm{BIPM}^{\mathrm{TMS}} \mathrm{H}\right\}^{-}$ligand appears to be bound to lanthanum in a similar manner in each complex, as evidenced by the mean endocyclic P-C and P-N bond distances and P1-C1-P2 angle in 2 [1.720(8), $1.607(7) \AA$ and $138.3(5)^{\circ}$, respectively] being statistically indistinguishable to the corresponding values in $\left[\mathrm{La}\left(\mathrm{BIPM}^{\mathrm{TMS}} \mathrm{H}\right)(\mathrm{I})_{2}(\mathrm{THF})\right]\left[1.734(8), 1.610(7) \AA\right.$ and $135.9(5)^{\circ}$, respectively] [13].

Figure 3. Molecular structure of $22 \mathrm{C}_{7} \mathrm{H}_{8}$ with selected atom labelling. Displacement ellipsoids are drawn at 50\% probability, with lattice solvent and non-methanide hydrogen atoms omitted for clarity.

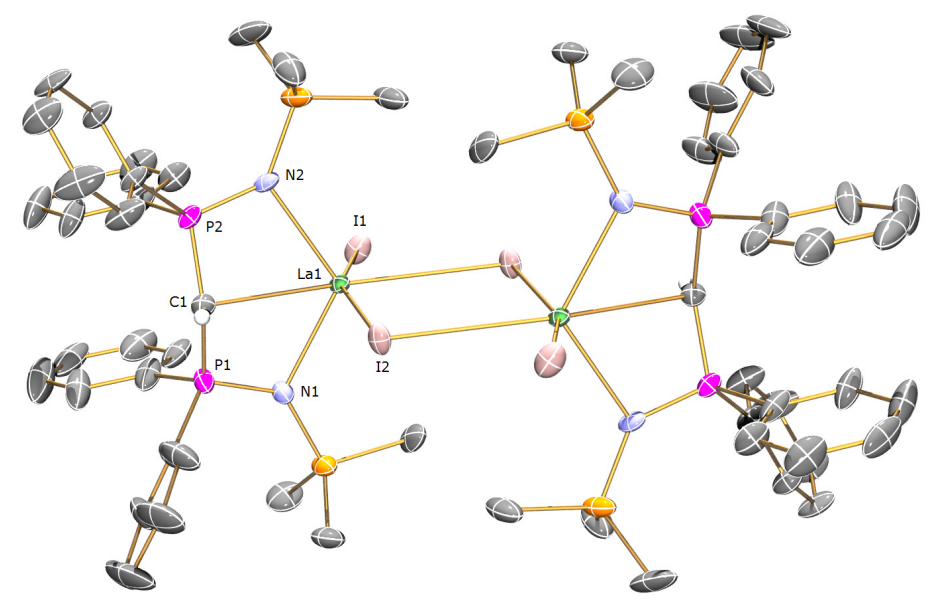


We have previously reported the conversion of $\left[\mathrm{Ln}\left(\mathrm{BIPM}^{\mathrm{TMS}} \mathrm{H}\right)(\mathrm{I})_{2}(\mathrm{THF})\right](\mathrm{Ln}=\mathrm{Ce}, \mathrm{Y})$ to $\left[\mathrm{Ce}\left(\mathrm{BIPM}^{\mathrm{TMS}}\right)(\mathrm{I})(\mathrm{DME})\right]$ and $\left[\mathrm{Y}\left(\mathrm{BIPM}^{\mathrm{TMS}}\right)(\mathrm{I})(\mathrm{THF})_{2}\right]$, respectively, via reaction with $[\mathrm{K}(\mathrm{Bn})]$. This approach provides access to rare earth $\left\{\mathrm{BIPM}^{\mathrm{TMS}}\right\}^{2-}$ derived methanediide complexes for both the larger and smaller rare earths (Ce, and $\mathrm{Y}$, respectively, Table 1). To fully investigate the nature of the $\left\{\mathrm{BIPM}^{\mathrm{R}}\right\}^{2-}$ ligand on the stability of these systems we have investigated the $N$-Mesityl variant of $\left\{\mathrm{BIPM}^{\mathrm{TMS}}\right\}^{2-}$, namely $\left\{\mathrm{BIPM}{ }^{\mathrm{Mes}}\right\}^{2-}$.

\subsection{Preparation of $\left\{B I P M^{M e s} H\right\}$ Rare Earth Methanides}

We have previously reported the preparation of $\left[\mathrm{Ln}\left(\mathrm{BIPM}^{\mathrm{Mes}} \mathrm{H}\right)(\mathrm{I})_{2}(\mathrm{THF})_{2}\right](\mathrm{Ln}=\mathrm{La}, \mathrm{Ce}, \mathrm{Pr}, \mathrm{Nd}$, $\mathrm{Sm})$ in variable yield $(40-78 \%)$ via the reaction of $\left[\operatorname{Ln}(\mathrm{I})_{3}(\mathrm{THF})_{n}\right]$ with $\left[\left\{\mathrm{K}\left(\mathrm{BIPM}^{\mathrm{Mes}} \mathrm{H}\right)\right\}_{2}\right][12,14]$. In contrast to the preparation of the $\left\{\mathrm{BIPM}^{\mathrm{TMS}} \mathrm{H}\right\}^{-}$analogues (vide supra), no forcing conditions or use of heavier group 1 ligand transfer reagents (e.g., $\left.\left[\mathrm{Cs}\left(\mathrm{BIPM}^{\mathrm{Mes}} \mathrm{H}\right)\right]\right)$ was required. This is likely due to the decreased steric bulk of the $\left\{\mathrm{BIPM}{ }^{\mathrm{Mes}} \mathrm{H}\right\}^{-}$ligand compared to $\left\{\mathrm{BIPM}{ }^{\mathrm{TMS}} \mathrm{H}\right\}^{-}$leading to more reactive ligand transfer reagents as the alkali metal is less sterically shielded.

As we had previously prepared $\left[\mathrm{Ln}\left(\mathrm{BIPM}^{\mathrm{Mes}} \mathrm{H}\right)(\mathrm{I})_{2}(\mathrm{THF})_{2}\right]$ for the larger rare earths $(\mathrm{Ln}=\mathrm{La}, \mathrm{Ce}$, Pr, Nd, Sm; See Table 1), we attempted to extend this series to investigate any changes in structure or reactivity imparted on the complex by varying the metal centre. Analogous to our previous reports, the reaction of half an equivalent of $\left[\left\{\mathrm{K}\left(\mathrm{BIPM}^{\mathrm{Mes}} \mathrm{H}\right)\right\}_{2}\right]$ with $\left[\mathrm{Ln}(\mathrm{I})_{3}(\mathrm{THF})_{3.5}\right](\mathrm{Ln}=\mathrm{Gd}$, Yb) afforded $\left[\mathrm{Gd}\left(\mathrm{BIPM}^{\mathrm{Mes}} \mathrm{H}\right)(\mathrm{I})_{2}(\mathrm{THF})_{2}\right], 3$, and $\left[\mathrm{Yb}\left(\mathrm{BIPM}^{\mathrm{Mes}} \mathrm{H}\right)(\mathrm{I})_{2}(\mathrm{THF})\right]$, 4, respectively (Scheme 3). Each complex was identified by elemental analyses, solution magnetic studies (vide infra) and by single crystal X-ray diffraction studies. However, while the X-ray diffraction data for $33 \mathrm{C}_{7} \mathrm{H}_{8}$ is of good quality $\left(R_{\text {int }}=0.034, R=0.0419, R_{w}=0.109\right)$ and confirmed its identity as $\left[\mathrm{Gd}\left(\mathrm{BIPM}^{\mathrm{Mes}} \mathrm{H}\right)(\mathrm{I})_{2}(\mathrm{THF})_{2}\right]$ $3 \mathrm{C}_{7} \mathrm{H}_{8}$, the data-set obtained for $43 \mathrm{C}_{7} \mathrm{H}_{8}$ is poor $\left(R_{\text {int }}=0.0744, R=0.1097, R_{w}=0.2865\right)$, and despite exhaustive attempts more satisfactory data could not be obtained. While the data-set collected on crystals of $43 \mathrm{C}_{7} \mathrm{H}_{8}$ is of poor quality and precludes any assessment of the metrical parameters of the complex, the connectivity is clear-cut, and together with elemental analysis and comparison to lighter rare earth analogues, we are confident in our assignment of $\mathbf{4}$. The difficulty in obtaining crystals of 4 of suitable quality for single crystal X-ray diffraction studies is perhaps surprising as $\left[\mathrm{Ln}\left(\mathrm{BIPM}^{\mathrm{Mes}} \mathrm{H}\right)(\mathrm{I})_{2}(\mathrm{THF})_{2}\right](\mathrm{Ln}=\mathrm{La}, \mathrm{Ce}, \mathrm{Pr}, \mathrm{Nd}, \mathrm{Sm}, \mathrm{Gd})$ all crystallise readily from toluene solutions to afford large crystals suitable for single crystal X-ray diffraction studies. The change in crystallinity is possibly due to 4 possessing only one THF molecule coordinated to ytterbium, compared to the two THF molecules coordinated in $\left[\mathrm{Ln}\left(\mathrm{BIPM}^{\mathrm{Mes}} \mathrm{H}\right)(\mathrm{I})_{2}(\mathrm{THF})_{2}\right](\mathrm{Ln}=\mathrm{La}, \mathrm{Ce}, \mathrm{Pr}, \mathrm{Nd}, \mathrm{Sm}, \mathrm{Gd})$ [12,14]. This variation in coordination number and ligand environment may lead to less efficient crystal packing, however, the lack in crystallinity may also be due to $\mathbf{4}$ not containing the optimal metal/ligand size ratio for crystal growth [21].

The solid-state structure of $33 \mathrm{C}_{7} \mathrm{H}_{8}$ is shown in Figure 4, with selected bond lengths and angles shown in Table $\mathrm{S} 1$. As $33 \mathrm{C}_{7} \mathrm{H}_{8}$ crystallises with the same cell settings as $\left[\mathrm{Ln}\left(\mathrm{BIPM}^{\mathrm{Mes}} \mathrm{H}\right)(\mathrm{I})_{2}(\mathrm{THF})_{2}\right]$ $(\mathrm{Ln}=\mathrm{La}, \mathrm{Ce}, \mathrm{Pr}, \mathrm{Nd}, \mathrm{Sm})[12,14]$, they adopt the same distorted pentagonal bipyramidal structure, with the gadolinium centre being coordinated by tridentate $\left\{\mathrm{BIPM}^{\mathrm{Mes}} \mathrm{H}\right\}^{-}[\mathrm{N} 1-\mathrm{Gd} 1-\mathrm{N} 2$ angle: 113.23(10 $)^{\circ}$ ], two iodides and two THF molecules. The two iodides can be considered as occupying the axial sites, with the I1-Gd1-I2 angle of $155.765(9)^{\circ}$ revealing the degree of distortion away from 
idealised pentagonal bipyramidal geometry due to the coordination of the bulky $\left\{\mathrm{BIPM}^{\mathrm{Mes}} \mathrm{H}\right\}^{-}$ligand. As expected, due to the lanthanide contraction, the bond distances about the gadolinium centre in $\mathbf{3}$ are generally shorter than those observed in $\left[\mathrm{Ln}\left(\mathrm{BIPM}^{\mathrm{Mes}} \mathrm{H}\right)(\mathrm{I})_{2}(\mathrm{THF})_{2}\right](\mathrm{Ln}=\mathrm{La}, \mathrm{Ce}, \mathrm{Pr}, \mathrm{Nd}, \mathrm{Sm})$, due to the smaller radius of $\mathrm{Gd}(\mathrm{III})$ (Table 1), and are each within the range of previously reported distances [24], but are otherwise unremarkable. The $\left\{\mathrm{BIPM}^{\mathrm{Mes}} \mathrm{H}\right\}^{-}$ligand in $\mathbf{3}$ appears to be bound to the metal centre in an analogous manner to $\left[\mathrm{Ln}\left(\mathrm{BIPM}^{\mathrm{Mes}} \mathrm{H}\right)(\mathrm{I})_{2}(\mathrm{THF})_{2}\right](\mathrm{Ln}=\mathrm{La}, \mathrm{Ce}, \mathrm{Pr}, \mathrm{Nd}, \mathrm{Sm})[12,14]$, as evidenced by the mean endocyclic P-C, P-N distances and P1-C1-P2 angle in 3 [1.723(4) $\AA, 1.626(3) \AA$ and $134.3(2)^{\circ}$, respectively] being statistically indistinguishable to corresponding values reported for $\left[\mathrm{Ln}\left(\mathrm{BIPM}^{\mathrm{Mes}} \mathrm{H}\right)(\mathrm{I})_{2}(\mathrm{THF})_{2}\right](\mathrm{Ln}=\mathrm{La}, \mathrm{Ce}, \mathrm{Pr}, \mathrm{Nd}, \mathrm{Sm})$ [ranges P-C: 1.719(4)-1.731(4) A; P-N: 1.612(3)-1.634(3) Å and P-C-P: 133.7(3)-134.1(2) ${ }^{\circ}$ [12,14].

Whilst we were successful in the preparation of $\left[\mathrm{Ln}\left(\mathrm{BIPM}^{\mathrm{Mes}} \mathrm{H}\right)(\mathrm{I})_{2}(\mathrm{THF})_{n}\right]$ for the larger rare earths $(\mathrm{Ln}=\mathrm{La}, \mathrm{Ce}, \mathrm{Pr}, \mathrm{Nd}, \mathrm{Sm}, \mathrm{Gd})$ and smaller rare earth ytterbium, we had difficulty in the preparation of analogues for intermediate sized rare earths, namely dysprosium and erbium (Table 1). It is difficult to follow reaction progress between $\left[\operatorname{Ln}(\mathrm{I})_{3}(\mathrm{THF})_{3.5}\right](\mathrm{Ln}=\mathrm{Dy}, \mathrm{Er})$ and half an equivalent of $\left[\left\{\mathrm{K}\left(\mathrm{BIPM}^{\mathrm{Mes}} \mathrm{H}\right)\right\}_{2}\right]$, as the highly paramagnetic nature of $\mathrm{Dy}(\mathrm{III})\left(4 f^{7}\right)$ and $\operatorname{Er}(\mathrm{III})\left(4 f^{9}\right)$ lead to inconclusive NMR spectra, and also because $\left[\operatorname{Ln}(\mathrm{I})_{3}(\mathrm{THF})_{3.5}\right]$ has low solubility in THF so the elimination of KI cannot be monitored easily as a suspension is observed throughout the reaction. As we followed the same preparative method that yielded $\left[\operatorname{Ln}\left(\mathrm{BIPM}^{\mathrm{Mes}} \mathrm{H}\right)(\mathrm{I})_{2}(\mathrm{THF})_{n}\right]$ (vide supra), we worked up the reaction mixture in a similar manner, namely filtration and recrystallisation from hot toluene solutions. In the cases of dysprosium and erbium this did not afford $\left[\mathrm{Ln}\left(\mathrm{BIPM}^{\mathrm{Mes}} \mathrm{H}\right)(\mathrm{I})_{2}(\mathrm{THF})_{n}\right](\mathrm{Ln}=\mathrm{Dy}, \mathrm{Er})$ as expected, but instead led to the isolation of the separated ion pair species $\left[\mathrm{Ln}\left(\mathrm{BIPM}^{\mathrm{Mes}} \mathrm{H}\right)_{2}\right]\left[\mathrm{BIPM}^{\mathrm{Mes}} \mathrm{H}\right](\mathrm{Ln}=\mathrm{Dy}, \mathbf{5 a} ; \mathrm{Er}, \mathbf{5 b})$ in moderate yields $(\mathbf{5 a} \mathbf{a}$ 39\%; 5b: $31 \%$, based on BIPM) (Scheme 3). Our hypothesis for the isolation of $\mathbf{5 a}-\mathbf{b}$ is that the reaction of $\left[\mathrm{Ln}(\mathrm{I})_{3}(\mathrm{THF})_{3.5}\right](\mathrm{Ln}=\mathrm{Dy}, \mathrm{Er})$ with half an equivalent of $\left[\left\{\mathrm{K}\left(\mathrm{BIPM}^{\mathrm{Mes}} \mathrm{H}\right)\right\}_{2}\right]$ proceeds sluggishly under ambient conditions, primarily due to the inherent insolubility of $\left[\operatorname{Ln}(\mathrm{I})_{3}(\mathrm{THF})_{3.5}\right](\mathrm{Ln}=\mathrm{Dy}, \mathrm{Er})$ in THF [25]. During workup, filtration separates insoluble $\left[\mathrm{Ln}(\mathrm{I})_{3}(\mathrm{THF})_{3.5}\right](\mathrm{Ln}=\mathrm{Dy}, \mathrm{Er})$ and yields a solution of $\left[\left\{\mathrm{K}\left(\mathrm{BIPM}^{\mathrm{Mes}} \mathrm{H}\right)\right\}_{2}\right]$ in excess to $\left[\mathrm{Ln}(\mathrm{I})_{3}(\mathrm{THF})_{3.5}\right](\mathrm{Ln}=\mathrm{Dy}, \mathrm{Er})$, which, when heated in toluene during attempted recrystallisation, would lead to a rapid reaction, where $\left[\operatorname{Ln}(\mathrm{I})_{3}(\mathrm{THF})_{3.5}\right](\operatorname{Ln}=$ Dy, Er) would effectively react with three equivalents of $\left[\left\{\mathrm{K}\left(\mathrm{BIPM}^{\mathrm{Mes}} \mathrm{H}\right)\right\}_{2}\right]$ to afford $\mathbf{5 a}-\mathbf{5} \mathbf{b}$, with concomitant elimination of KI.

Repeated attempts to prepare $\left[\mathrm{Ln}\left(\mathrm{BIPM}^{\mathrm{Mes}} \mathrm{H}\right)(\mathrm{I})_{2}(\mathrm{THF})_{n}\right](\mathrm{Ln}=\mathrm{Dy}, \mathrm{Er})$ by varying reaction times and solvents (THF, 1,2-dimethoxyethane, $\mathrm{Et}_{2} \mathrm{O}$ ) were not successful, and when forcing conditions were employed the reaction proceeded rapidly rather than in a slow and controlled manner, leading to isolation of $\mathbf{5 a}-\mathbf{b}$. Complexes $\mathbf{5 a}-\mathbf{b}$ were identified by solution magnetic moment measurements (vide infra), elemental analyses and by single crystal X-ray diffraction studies. 
Scheme 3. Preparation of 3-5a-b.

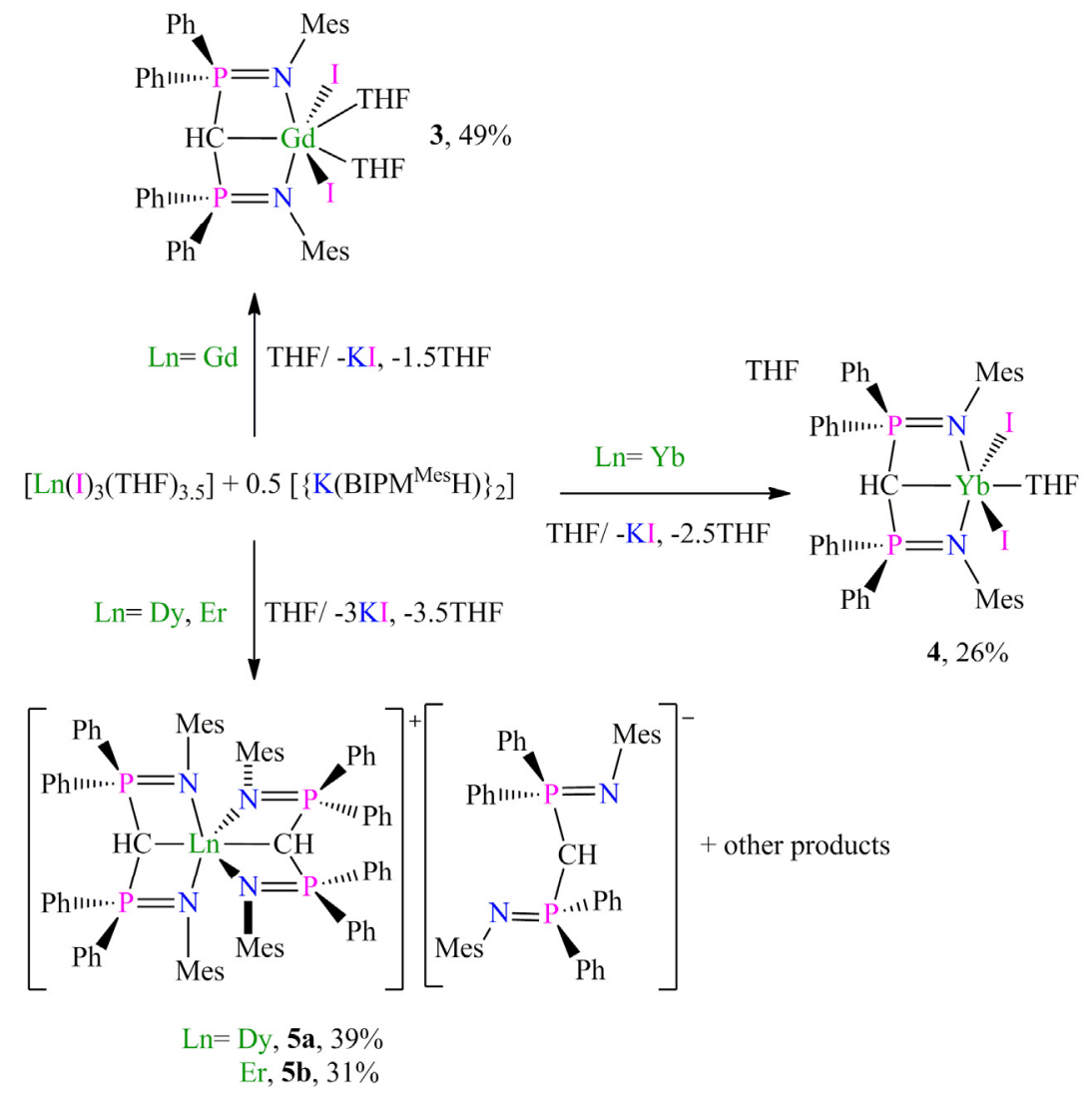

Figure 4. Molecular structure of $33 \mathrm{C}_{7} \mathrm{H}_{8}$ with selected atom labelling. Displacement ellipsoids are drawn at 50\% probability, with lattice solvent and non-methanide hydrogen atoms omitted for clarity.

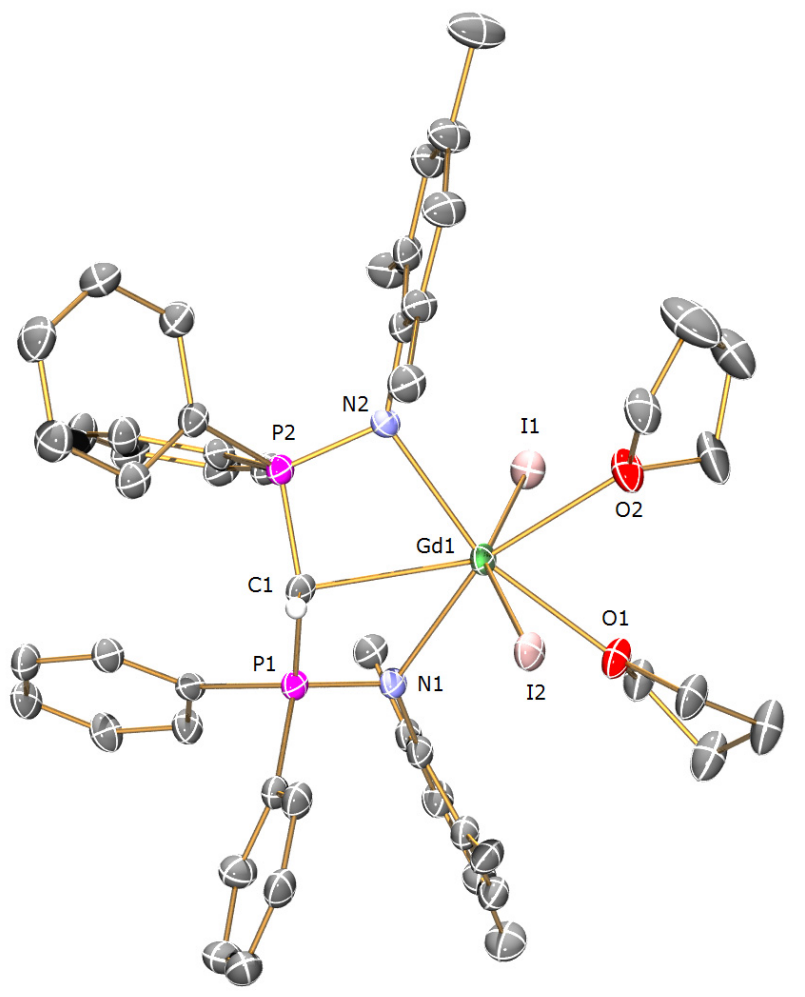


As complexes $\mathbf{5 a} 4 \mathrm{C}_{7} \mathrm{H}_{8}$ and $\mathbf{5 b} \quad 5 \mathrm{C}_{7} \mathrm{H}_{8}$ have very similar solid-state structures and metrical parameters, only $\mathbf{5 a} 4 \mathrm{C}_{7} \mathrm{H}_{8}$ is discussed in detail. Selected bond lengths and angles of $\mathbf{5 a} 4 \mathrm{C}_{7} \mathrm{H}_{8}$ and $\mathbf{5 b}$ ${ }_{5} \mathrm{C}_{7} \mathrm{H}_{8}$ are shown in Table S1. The cationic $\left[\mathrm{Dy}\left(\mathrm{BIPM}^{\mathrm{Mes}} \mathrm{H}\right)_{2}\right]^{+}$component of $\mathbf{5 a}$ is shown in Figure 5, while, for clarity, the anionic $\left[\mathrm{BIPM}^{\mathrm{Mes}} \mathrm{H}\right]^{-}$component is shown separately in Figure 6.

The dysprosium centre in $\mathbf{5 a}$ is coordinated by two mutually orthogonal $\left\{\mathrm{BIPM}^{\mathrm{Mes}} \mathrm{H}\right\}^{-}$ligands, each exhibiting a tridentate binding mode, leading to a distorted octahedral geometry. Each $\left\{\mathrm{BIPM}{ }^{\mathrm{Mes}} \mathrm{H}\right\}^{-}$is coordinated to dysprosium in a similar mode, as shown by the statistically indistinguishable Dy1-C1 [2.676(2) $\AA]$ and Dy1-C44 [2.679(2) $\AA]$ distances, but there is a variation in Dy-N distances, with each $\left\{B I P M{ }^{M e s} H\right\}^{-}$exhibiting one shorter Dy-N distance [Dy1-N2: 2.3445(18) $\AA$; Dy1-N3: 2.3584(17) $\AA$ ] and

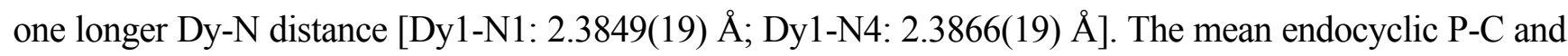
P-N distances, and P-C-P angle in the cationic component of 5a [1.742(2), 1.632(2) $\AA$ and 128.65(13) respectively] are similar to the corresponding distances in $\left[\mathrm{Ln}\left(\mathrm{BIPM}^{\mathrm{Mes}} \mathrm{H}\right)(\mathrm{I})_{2}(\mathrm{THF})_{2}\right](\mathrm{Ln}=\mathrm{La}, \mathrm{Ce}, \mathrm{Pr}, \mathrm{Nd}$, Sm) [12,14], but there is a slight elongation of the P-C bonds [5a: 1.742(2) A compared to range 1.719(4)1.731(4) $\AA$ ] and lowering of the P-C-P angle [5a: 128.65(13) ${ }^{\circ}$ compared to range 133.7(3)-134.1(2) ${ }^{\circ}$, which is likely a reflection of the coordination of two bulky $\left\{B I P M^{M e s} H\right\}^{-}$ligands to one metal centre leading to increased steric hindrance about the endocyclic ring.

The anionic component of 5a $\left[\mathrm{BIPM}^{\mathrm{Mes}} \mathrm{H}\right]^{-}$exhibits shortened endocyclic P-C and P-N distances [mean values of 1.709(2) and $1.592 \AA$, respectively] and a larger P-C-P angle [P5-C87-P6: $\left.133.89(15)^{\circ}\right]$ in comparison to the $\left\{\mathrm{BIPM}^{\mathrm{Mes}} \mathrm{H}\right\}^{-}$ligands in the cationic component, due to the anion not being coordinated to a metal centre. The P-C and P-N bonds in the N-P-C-P-N framework of the anionic $\left[\mathrm{BIPM}^{\mathrm{Mes}} \mathrm{H}\right]^{-}$fragment are shorter, and longer, respectively, than the distances reported in $\mathrm{BIPM}^{\mathrm{Mes}} \mathrm{H}_{2}$ [26], suggesting a degree of delocalisation of charge about the N-P-C-P-N framework.

Figure 5. Cationic component of 5a $4 \mathrm{C}_{7} \mathrm{H}_{8}$. Displacement ellipsoids are drawn at $50 \%$ probability, with lattice solvent and non-methanide hydrogen atoms omitted for clarity.

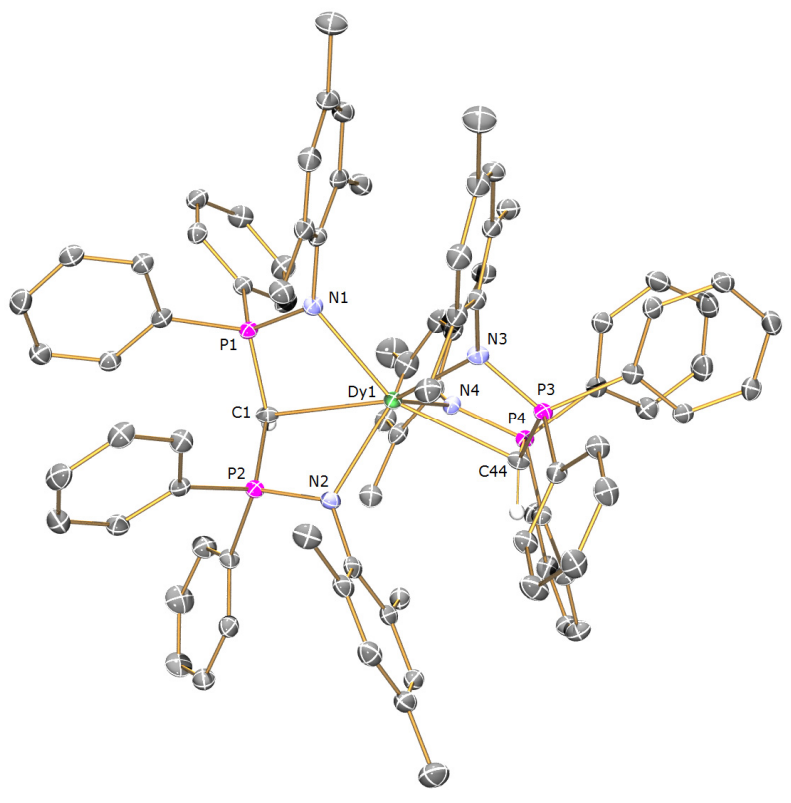


Figure 6. Anionic component of $\mathbf{5 a} 4 \mathrm{C}_{7} \mathrm{H}_{8}$. Displacement ellipsoids are drawn at $50 \%$ probability, with lattice solvent and non-methanide hydrogen atoms omitted for clarity.

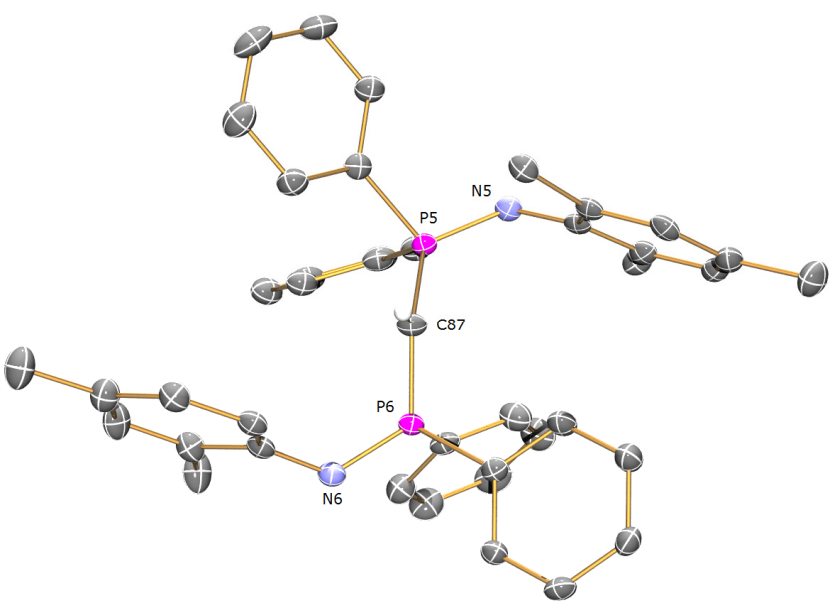

With $\left[\mathrm{Ln}\left(\mathrm{BIPM}^{\mathrm{Mes}} \mathrm{H}\right)(\mathrm{I})_{2}(\mathrm{THF})_{2}\right](\mathrm{Ln}=\mathrm{Ce}, \mathrm{Pr}, \mathrm{Nd}, \mathrm{Sm})$ and $\mathbf{3}$ in hand, we attempted to prepare a range of $\left\{\mathrm{BIPM}^{\mathrm{Mes}}\right\}^{2-}$ derived rare earth methanediides in an analogous manner to our previously reported $\left[\mathrm{La}\left(\mathrm{BIPM}^{\mathrm{Mes}}\right)(\mathrm{I})(\mathrm{THF})_{3}\right] \quad[12]$, which was prepared via the reaction of $\left[\mathrm{La}\left(\mathrm{BIPM}{ }^{\mathrm{Mes}} \mathrm{H}\right)(\mathrm{I})_{2}(\mathrm{THF})_{2}\right]$ with $[\mathrm{K}(\mathrm{Bn})]$. Unfortunately this preparative route proved to be capricious (vide infra), with a potential cause of the reaction not proceeding smoothly being the ineffectiveness of the labile coordinated THF molecules to fully saturate and stabilise the rare earth centre during the reaction. Replacement of these THF molecules with a bulkier bidentate donor solvent, namely TMEDA ( $N^{\prime}, N^{\prime}, N^{\prime \prime}, N^{\prime \prime}$-tetramethylethylenediamine) was predicted to provide increased saturation of the rare earth metal centre and lead to an improved route to complexes of the formula $\left[\mathrm{Ln}\left(\mathrm{BIPM}^{\mathrm{Mes}}\right)(\mathrm{I})(\mathrm{S})_{n}\right](\mathrm{S}=$ donor solvent $)$.

We initially investigated the lanthanum congener, as its $\mathrm{La}(\mathrm{III}) 4 f^{\circ}$ state is diamagnetic allowing us to follow the reaction progress easily by NMR spectroscopy. The straightforward reaction of $\left[\mathrm{La}\left(\mathrm{BIPM}^{\mathrm{Mes}} \mathrm{H}\right)(\mathrm{I})_{2}(\mathrm{THF})_{2}\right] \quad$ [12] with TMEDA in THF solution over $18 \mathrm{~h}$ afforded $\left[\mathrm{La}\left(\mathrm{BIPM}^{\mathrm{Mes}} \mathrm{H}\right)(\mathrm{I})_{2}(\mathrm{TMEDA})\right], \mathbf{6 a}$, in essentially quantitative yield (Scheme 4).

NMR spectroscopy performed on $\mathbf{6 a}$ revealed it to have similar resonances to $\left[\mathrm{La}\left(\mathrm{BIPM}{ }^{\mathrm{Mes}} \mathrm{H}\right)(\mathrm{I})_{2}(\mathrm{THF})_{2}\right]$, with the ${ }^{1} \mathrm{H}$ and ${ }^{13} \mathrm{C}\left\{{ }^{1} \mathrm{H}\right\}$ NMR spectra of $\mathbf{6 a}$ exhibiting resonances for the methanide hydrogen and carbon at $3.91 \mathrm{ppm}\left({ }^{2} J_{P H}=8.8 \mathrm{~Hz}\right)$, and $8.44 \mathrm{ppm}\left(J_{\mathrm{PC}}=138 \mathrm{~Hz}\right)$, respectively, which are both slightly downfield compared to the equivalent resonances reported for $\left[\mathrm{La}\left(\mathrm{BIPM}{ }^{\mathrm{Mes}} \mathrm{H}\right)(\mathrm{I})_{2}(\mathrm{THF})_{2}\right]\left(3.36 \mathrm{ppm},{ }^{2} J_{\mathrm{PH}}=14.5 \mathrm{~Hz}\right.$ and $\left.5.73 \mathrm{ppm}, J_{\mathrm{PC}}=136 \mathrm{~Hz}\right) .{ }^{12}$ The ${ }^{31} \mathrm{P}\left\{{ }^{1} \mathrm{H}\right\}$ NMR spectrum of 6 a exhibits a resonance at $15.70 \mathrm{ppm}$ which is slightly downfield to the corresponding resonance reported for $\left[\mathrm{La}\left(\mathrm{BIPM}^{\mathrm{Mes}} \mathrm{H}\right)(\mathrm{I})_{2}(\mathrm{THF})_{2}\right](11.46 \mathrm{ppm})$ [12].

While elemental analysis and NMR spectroscopy supported the formulation of $\mathbf{6 a}$, a single crystal $\mathrm{X}$-ray diffraction study was performed to confirm its structure. The solid-state structure of $\mathbf{6 a} 3 \mathrm{C}_{7} \mathrm{H}_{8}$ is shown in Figure 7, with selected bond lengths and angles complied in Table S1. The lanthanum centre in 6a adopts a heavily distorted pentagonal bipyramidal geometry with the two iodides occupying the axial sites [I1-La1-I2 angle: $\left.158.395(12)^{\circ}\right]$. The tridentate $\left\{\mathrm{BIPM}^{\mathrm{Mes}} \mathrm{H}\right\}^{-}$[N1-La1-N2 angle: $\left.110.72(13)^{\circ}\right]$ and the two amine nitrogens of TMEDA occupy the equatorial sites. The La1-N ${ }_{\text {TMEDA }}$ distances [La1-N3: 2.852(5) $\AA$; La1-N4: 2.844(4) $\AA$ ] are far longer than the La1-N ${ }_{\text {BIPM }}$ 
distances [La1-N1: 2.564(4) $\AA$; La1-N2: $2.526(4) \AA]$ consistent with the $\mathrm{N}-{ }^{-} \mathrm{P}^{+}{ }^{+} \mathrm{C}-{ }^{-} \mathrm{P}^{-} \mathrm{N}^{-}$charge distribution about the $\left\{\mathrm{BIPM}^{\mathrm{Mes}} \mathrm{H}\right\}^{-}$framework leading to an increased electrostatic interaction between La1 and the imino nitrogens. Despite the variation of donor solvent coordinated to lanthanum,

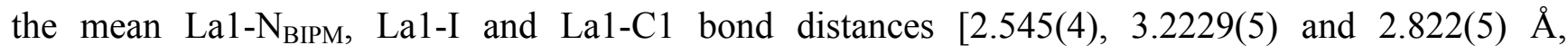
respectively] are very similar to, if not statistically indistinguishable, from the corresponding distances in $\left[\mathrm{La}\left(\mathrm{BIPM}^{\mathrm{Mes}} \mathrm{H}\right)(\mathrm{I})_{2}(\mathrm{THF})_{2}\right]$ [2.537(3), 3.2042(4) and 2.833(4) $\AA$, respectively] [12]. Similarly, the $\left\{\mathrm{BIPM}^{\mathrm{Mes}} \mathrm{H}\right\}^{-}$ligand exhibits statistically indistinguishable endocyclic P-C and P-N distances [mean distances: $1.732(5)$ and $1.621(5) \AA$, respectively], and P1-C1-P2 angle [134.1(3) ${ }^{\circ}$ to the THF congener [1.726(4) $\AA, 1.617(3) \AA$ and $133.8(2)^{\circ}$, respectively] [12].

Following the successful isolation of $\mathbf{6 a}$, we prepared a heavier rare earth analogue, namely $\left[\mathrm{Gd}\left(\mathrm{BIPM}^{\mathrm{Mes}} \mathrm{H}\right)(\mathrm{I})_{2}(\mathrm{TMEDA})\right]$, 6b, via the same methodology. As Gd(III) is smaller than La(III) (Table 1) this would provide us with a range of metal sizes to fully investigate if the size of the metal centre has any effect on the successful preparation of our target $\left\{\mathrm{BIPM}^{\mathrm{Mes}}\right\}^{2-}$ methanediide complexes (vide infra). Complex $\mathbf{6 b}$ was prepared and utilised in situ in attempted deprotonation/salt elimination reactions, but a small sample was recrystallised from toluene to afford single crystals suitable for $\mathrm{X}$-ray diffraction studies. Although $\mathbf{6 b}$ crystallises in a different cell setting to $\mathbf{6 a}(C \mathrm{mca} v s$. $P-1)$, leading to the TMEDA molecule possessing positional disorder about the mirror plane, the overall structures are very similar with the gadolinium centre in $\mathbf{6 b}$ adopting a heavily distorted pentagonal bipyramidal geometry. As expected due to the lanthanide contraction the bond distances about the gadolinium centre in $\mathbf{6 b}$ are each shortened by $c a$. 0.07-0.14 $\AA$ compared to the corresponding distances about lanthanum in $\mathbf{6 a}$, and are all well within the range of previously reported bond distances [24].

With $\left[\mathrm{Ln}\left(\mathrm{BIPM}^{\mathrm{Mes}} \mathrm{H}\right)(\mathrm{I})_{2}(\mathrm{THF})_{2}\right](\mathrm{Ln}=\mathrm{La}, \mathrm{Ce}, \mathrm{Pr}, \mathrm{Gd})$ and $\left[\mathrm{Ln}\left(\mathrm{BIPM}^{\mathrm{Mes}} \mathrm{H}\right)(\mathrm{I})_{2}(\mathrm{TMEDA})\right](\mathrm{Ln}=$ $\mathrm{La}, \mathrm{Gd})$ secured, we turned our focus to the preparation of $\left\{\mathrm{BIPM}^{\mathrm{Mes}}\right\}^{2-}$ derived rare earth methandediide complexes.

Scheme 4. Preparation of $6 a-b$.

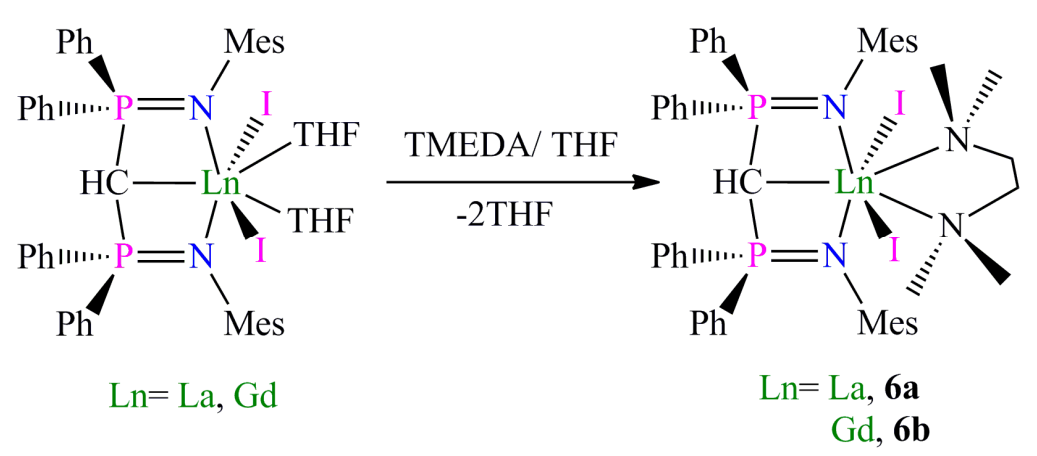


Figure 7. Molecular structure of $\mathbf{6 a} 3 \mathrm{C}_{7} \mathrm{H}_{8}$ with selected atom labelling. Displacement ellipsoids are drawn at 50\% probability, with lattice solvent and non-methanide hydrogen atoms omitted for clarity. The molecular structure of $6 \mathbf{b} 2 \mathrm{C}_{7} \mathrm{H}_{8}$ is very similar.

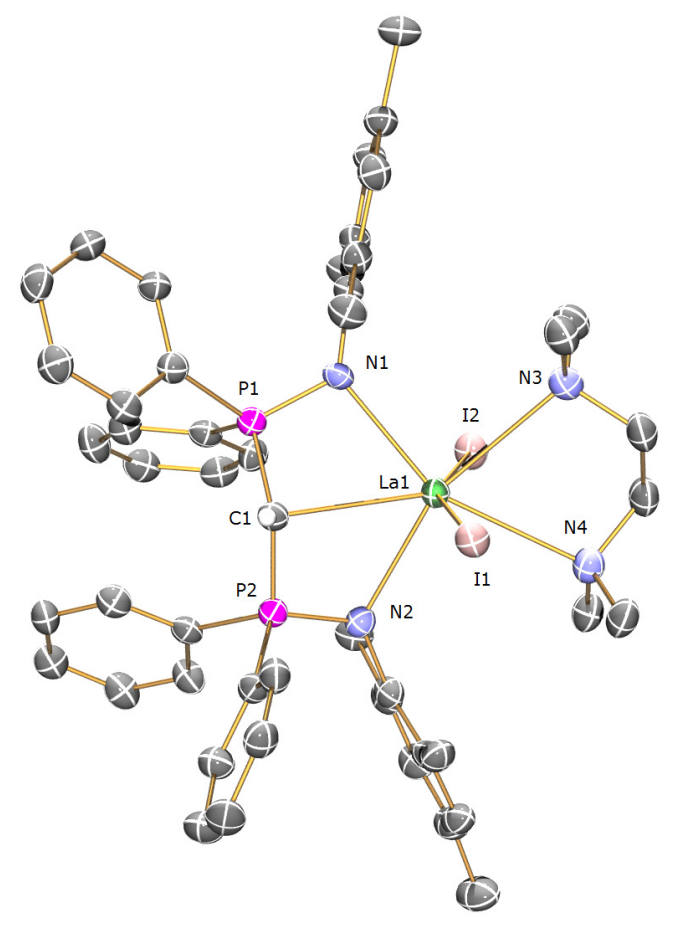

\subsection{Attempted Preparation of BIPM Mes Rare Earth Carbene Complexes}

We have previously reported that the reaction of $\left[\mathrm{La}\left(\mathrm{BIPM}^{\mathrm{Mes}} \mathrm{H}\right)(\mathrm{I})_{2}(\mathrm{THF})\right]$ with $[\mathrm{K}(\mathrm{Bn})]$ afforded the methanediide complex $\left[\mathrm{La}\left(\mathrm{BIPM}^{\mathrm{Mes}}\right)(\mathrm{I})(\mathrm{THF})_{3}\right]$ in $53 \%$ yield [12]. Unfortunately, this reaction appears to be capricious in nature, and despite following the reported methodology the reaction often yields a mixture of products from which $\left[\mathrm{La}\left(\mathrm{BIPM}^{\mathrm{Mes}}\right)(\mathrm{I})(\mathrm{THF})_{3}\right]$ cannot be isolated cleanly. As NMR spectroscopy revealed a mixture of products, of which none could be unambiguously identified, the reaction mixture was recrystallised from toluene which afforded $\left[\mathrm{La}\left(\mathrm{BIPM}^{\mathrm{Mes}}\right)\left(\mathrm{BIPM}^{\mathrm{Mes}} \mathrm{H}\right)\right]$, 7a, in $8 \%$ yield. The low yield of $\mathbf{7 a}$ is a reflection of the reaction not proceeding smoothly and affording a mixture of products, of which only $7 \mathbf{a}$ was crystalline and able to be extracted cleanly. Complex 7a was identified by single crystal X-ray diffraction studies (vide infra), NMR studies and elemental analysis. The ${ }^{31} \mathrm{P}\left\{{ }^{1} \mathrm{H}\right\}$ NMR spectrum of 7a exhibits two singlet resonances, at 2.88 and $10.51 \mathrm{ppm}$, which are assigned to the methanediide and methanide centres, respectively, by comparison to the resonances reported for $\left[\mathrm{La}\left(\mathrm{BIPM}^{\mathrm{Mes}}\right)(\mathrm{I})(\mathrm{THF})_{3}\right](4.84 \mathrm{ppm})$ and $\left[\mathrm{La}\left(\mathrm{BIPM}^{\mathrm{Mes}} \mathrm{H}\right)(\mathrm{I})_{2}(\mathrm{THF})_{2}\right](11.46$ ppm) [12]. The ${ }^{1} \mathrm{H}$ and ${ }^{13} \mathrm{C}\left\{{ }^{1} \mathrm{H}\right\}$ NMR spectra of 7a reveal methanide resonances of 2.26 (no coupling observed) and $4.59 \mathrm{ppm}\left(J_{\mathrm{PC}}=127 \mathrm{~Hz}\right)$, which are both upfield of the values reported for $\left[\mathrm{La}\left(\mathrm{BIPM}^{\mathrm{Mes}} \mathrm{H}\right)(\mathrm{I})_{2}(\mathrm{THF})_{2}\right]\left(3.36 \mathrm{ppm},{ }^{2} J_{\mathrm{PH}}=14.5 \mathrm{~Hz}\right.$ and $5.73 \mathrm{ppm}, J_{\mathrm{PC}}=136 \mathrm{~Hz}$, respectively), while the methanediide is observed in the ${ }^{13} \mathrm{C}\left\{{ }^{1} \mathrm{H}\right\}$ NMR spectrum of $7 \mathbf{a}$ at $45.06 \mathrm{ppm}$, which is also upfield to the value reported for $\left[\mathrm{La}\left(\mathrm{BIPM}^{\mathrm{Mes}}\right)(\mathrm{I})(\mathrm{THF})_{3}\right]\left(58.76 \mathrm{ppm}, J_{\mathrm{PC}}=148.4 \mathrm{~Hz}\right)$ [12].

The isolation of $\mathbf{7 a}$ is reminiscent of our attempts to prepare $\left[\mathrm{La}\left(\mathrm{BIPM}^{\mathrm{TMS}}\right)(\mathrm{Bn})(\mathrm{THF})_{n}\right]$ via the reaction of $\left[\mathrm{La}(\mathrm{Bn})_{3}(\mathrm{THF})_{3}\right]$ and $\mathrm{BIPM}^{\mathrm{TMS}} \mathrm{H}_{2}$ which instead afforded $\left[\mathrm{La}\left(\mathrm{BIPM}^{\mathrm{TMS}}\right)\left(\mathrm{BIPM}{ }^{\mathrm{TMS}} \mathrm{H}\right)\right]$, the 
$\mathrm{BIPM}^{\mathrm{TMS}}$ analogue of $\mathbf{7 a}[16]$. In the cases of both $\mathbf{7 a}$ and $\left[\mathrm{La}\left(\mathrm{BIPM}^{\mathrm{TMS}}\right)\left(\mathrm{BIPM}^{\mathrm{TMS}} \mathrm{H}\right)\right]$, the observed products are likely due to the instability of the intermediate complex $\left[\mathrm{La}\left(\mathrm{BIPM}^{\mathrm{Mes}} \mathrm{H}\right)(\mathrm{Bn})(\mathrm{I})(\mathrm{THF})_{n}\right]$ or $\left[\mathrm{La}\left(\mathrm{BIPM}^{\mathrm{TMS}} \mathrm{H}\right)(\mathrm{Bn})_{2}(\mathrm{THF})_{n}\right]$, which would each be susceptible to ligand scrambling due to the highly labile nature of lanthanide alkyl bonds.

As the preparation of $\left[\mathrm{La}\left(\mathrm{BIPM}^{\mathrm{Mes}}\right)(\mathrm{I})(\mathrm{THF})_{3}\right]$ via the reaction of $\left[\mathrm{La}\left(\mathrm{BIPM}^{\mathrm{Mes}} \mathrm{H}\right)(\mathrm{I})_{2}(\mathrm{THF})_{2}\right]$ with $[\mathrm{K}(\mathrm{Bn})]$ proved to be unreliable we attempted the reaction with other rare earth metals to investigate of the size of the metal present affected the result of the reaction. Also, in an attempt to stabilise the postulated "[ $\left.\mathrm{Ln}\left(\mathrm{BIPM}^{\mathrm{Mes}} \mathrm{H}\right)(\mathrm{Bn})(\mathrm{I})(\mathrm{THF})_{n}\right]$ " intermediate, which we hypothesise is undergoing ligand scrambling during reaction, we varied both the alkyl and coordinated solvent present. The alkyl could be substituted by utilising a base that is bulkier than $[\mathrm{K}(\mathrm{Bn})]$, namely $\left[\mathrm{K}\left(\mathrm{CHPh}_{2}\right)\right]$ or $\left[\mathrm{K}\left(\mathrm{CPh}_{3}\right)\right]$, while the coordinated solvent was varied by utilising $\mathbf{6 a - b}$ in place of $\left[\operatorname{Ln}\left(\mathrm{BIPM}^{\mathrm{Mes}} \mathrm{H}\right)(\mathrm{I})_{2}(\mathrm{THF})_{2}\right]$.

Unfortunately the reactions of $\left[\mathrm{Ln}\left(\mathrm{BIPM}^{\mathrm{Mes}} \mathrm{H}\right)(\mathrm{I})_{2}(\mathrm{THF})\right](\mathrm{Ln}=\mathrm{La}, \mathrm{Ce}, \mathrm{Pr}, \mathrm{Gd})$ or $\mathbf{6 a}-\mathbf{b}$ with $[\mathrm{K}(\mathrm{R})](\mathrm{R}$ $\left.=\mathrm{Bn}, \mathrm{CHPh}_{2}, \mathrm{CPh}_{3}\right)$ did not afford $\left[\mathrm{Ln}\left(\mathrm{BIPM}^{\mathrm{Mes}}\right)(\mathrm{I})(\mathrm{S})_{n}\right]$ as anticipated, but instead led to mixtures of products in each case. The only isolable and identifiable products from these reactions were 7a, $\left[\mathrm{Ce}\left(\mathrm{BIPM}^{\mathrm{Mes}}\right)\left(\mathrm{BIPM}^{\mathrm{Mes}} \mathrm{H}\right)\right], \mathbf{7 b},\left[\operatorname{Pr}\left(\mathrm{BIPM}^{\mathrm{Mes}}\right)\left(\mathrm{BIPM}^{\mathrm{Mes}} \mathrm{H}\right)\right], \mathbf{7}$, or $\left[\mathrm{Gd}\left(\mathrm{BIPM}^{\mathrm{Mes}}\right)\left(\mathrm{BIPM}^{\mathrm{Mes}} \mathrm{H}\right)\right]$, 7d, each in low yields (Scheme 5). Complexes $\mathbf{7 b}-\mathbf{d}$ were each identified by single crystal X-ray diffraction studies (vide infra), and while a clean sample of $\mathbf{7 b}$ was isolated which allowed full characterisation (elemental analysis and solution magnetic studies), isolated samples of $\mathbf{7 c}$ and $\mathbf{7 d}$ were contaminated with impurities which precluded full analysis. Despite the lack of full characterisation for 7c and 7d we are confident our formulation is correct as they are analogous to $\mathbf{7 a - b}$, and it appears that varying the size of the metal present has little effect on the outcome of the reaction.

Scheme 5. Preparation of $7 \mathbf{a}-\mathbf{d}$.

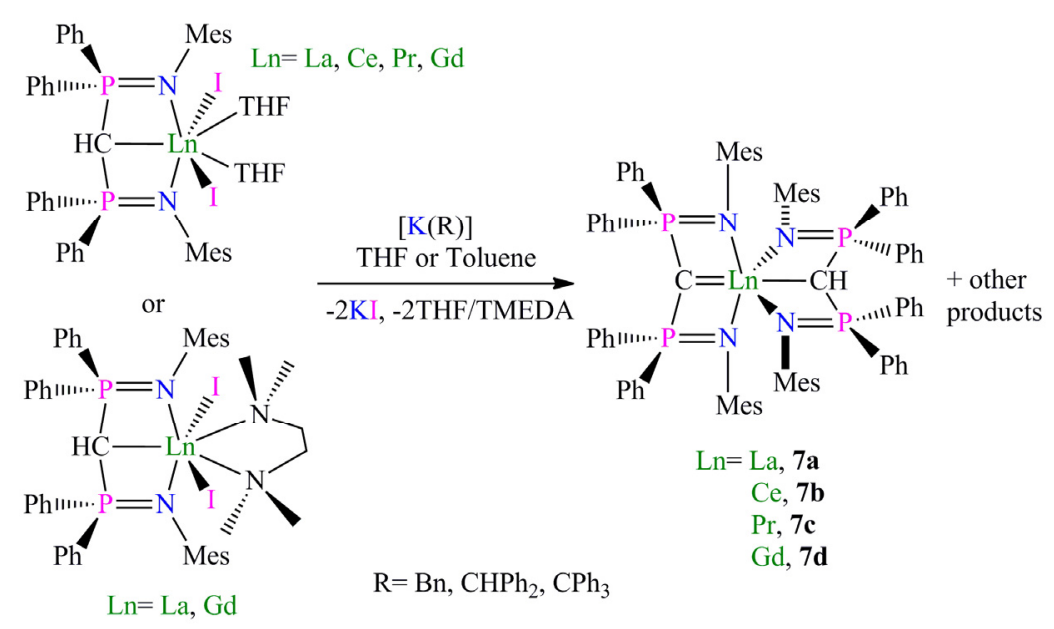


Figure 8. Molecular structure of $7 \mathbf{a} 3 \mathrm{C}_{7} \mathrm{H}_{8}$ with selected atom labelling. Displacement ellipsoids are drawn at 50\% probability, with lattice solvent and non-methanide hydrogen atoms omitted for clarity. The molecular structures of $7 \mathbf{b}-\mathbf{d}$ are very similar.

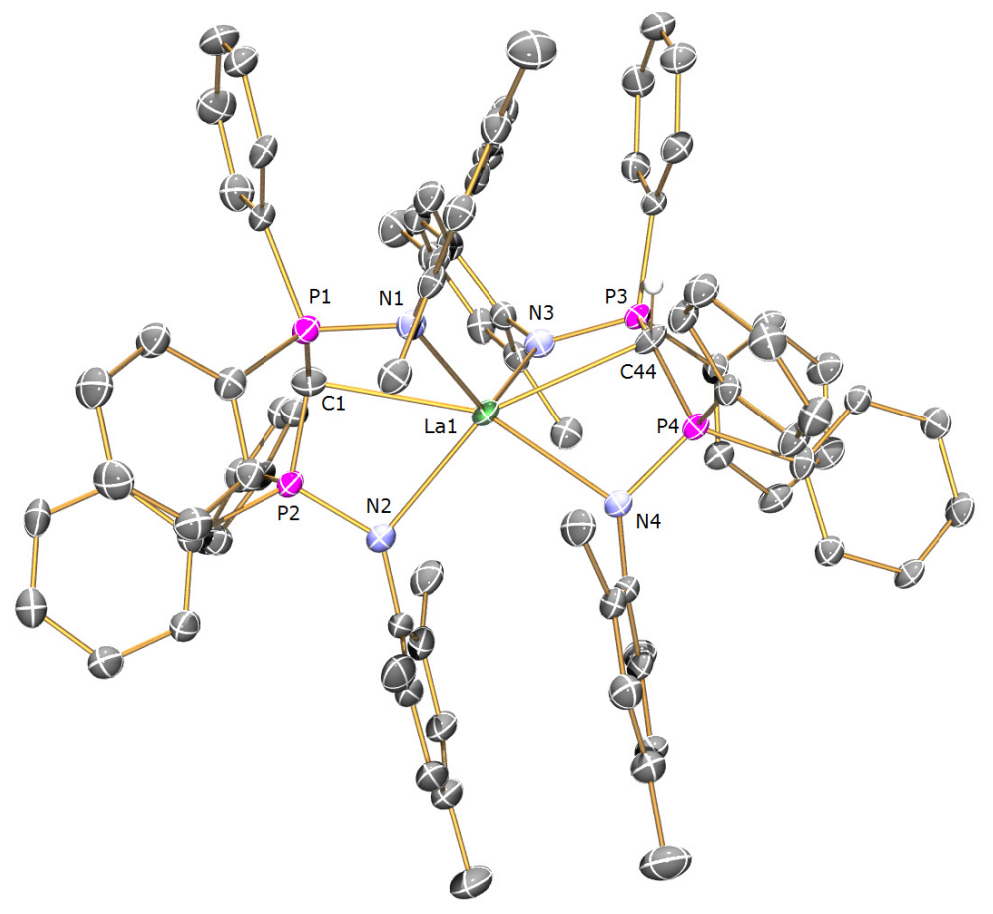

The complexes 7a-d exhibit very similar solid-state structures, with the rare earth metal coordinated by mutually orthogonal $\left\{\mathrm{BIPM}^{\mathrm{Mes}}\right\}^{2-}$ and $\left\{\mathrm{BIPM}^{\mathrm{Mes}} \mathrm{H}\right\}^{-}$ligands, each bound in a tridentate fashion. A representative structure of $7 \mathbf{a} 3 \mathrm{C}_{7} \mathrm{H}_{8}$ is shown in Figure 8 with selected bond lengths and angles for each complex shown in Table S1. Despite exhibiting the same overall structure there is a variation in metrical parameters between $\mathbf{7 a}, \mathbf{c}-\mathbf{d}$ and $\mathbf{7 b}$, which we propose is due to a variation in solvent of crystallisation. As each of $\mathbf{7 a}-\mathbf{d}$ exhibit one $\left\{\mathrm{BIPM}^{\mathrm{Mes}} \mathrm{H}\right\}^{-}$ligand bound to the metal centre as a methanide and one $\left\{\mathrm{BIPM}^{\mathrm{Mes}}\right\}^{2-}$ ligand bound as a methanediide, varying Ln-C distances would be expected as the metal centre would have an increased electrostatic interaction to the dianionic methanediide centre over the monoanionic methanide centre. This is the case for $\mathbf{7 b}$, which exhibits a longer Ce1-C1 distance of 2.819(11) A, and a shorter Ce1-C44 distance of 2.681(11) $\AA$, which leads to the assignment of $\mathrm{C} 1$ as being the methanide centre, and $\mathrm{C} 44$ being the methanediide centre. This is also analogous to the previously reported BIPM $^{\text {TMS }}$ congeners $\left[\mathrm{Ln}\left(\mathrm{BIPM}^{\mathrm{TMS}}\right)\left(\mathrm{BIPM}^{\mathrm{TMS}} \mathrm{H}\right)\right](\mathrm{Ln}=\mathrm{La}, \mathrm{Ce}, \mathrm{Pr}, \mathrm{Sm}, \mathrm{Gd})$, which each exhibit one long and one short Ln-C interaction [16].

However, in the cases of $\mathbf{7 a}$ and $\mathbf{7} \mathbf{c}-\mathbf{d}$, each $\left\{\mathrm{BIPM}^{\mathrm{Mes}}\right\}$ ligand appears to be bound to the metal in an identical manner, which is exemplified by statistically indistinguishable Ln-C bond distances in

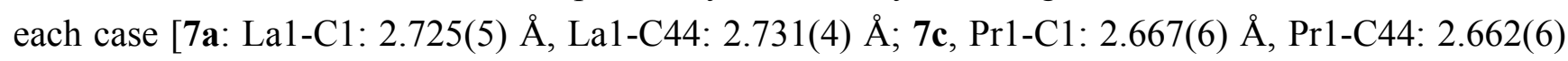
$\AA$; 7d, Gd1-C1: 2.605(11) $\AA$, Gd1-C44: 2.573(10) $\AA]$. We propose that this variation in coordination is simply an artefact of crystallisation, with the crystal packing in $7 \mathbf{a}, \mathbf{c}-\mathbf{d}$ being random, with the resulting data-set revealing an averaged geometry about the metal centre leading to equivalent Ln-C bond distances. This is supported by the mean Lal-C distances in 7a of 2.728(5) $\AA$ being intermediate to the Ce1-C distances in $7 \mathbf{b}$ of 2.681(11) and 2.819(11) $\AA$, which would be expected if the two bond 
distances were averaged out. The other possibility is that each $\left\{\mathrm{BIPM}^{\mathrm{Mes}}\right\}$ ligand in $\mathbf{7 a}$ is bound as a methanide leading to a formal oxidation state assignment of $\mathrm{La}$ (II), analogous to the previously reported $\left[\mathrm{Sm}\left(\mathrm{BIPM}^{\mathrm{Mes}} \mathrm{H}\right)_{2}\right]$ [27], but this is easily ruled out by $7 \mathbf{a}$ being diamagnetic and its ${ }^{31} \mathrm{P}\left\{{ }^{1} \mathrm{H}\right\}$ NMR spectrum exhibiting two resonances consistent with the presence of two different ligand environments.

As expected due to the lanthanide contraction (Table 1) [19], there is a shortening of the mean Ln-C and Ln-N bond distances across the series from $7 \mathbf{a}$ to $\mathbf{7 d}$, but these distances are otherwise unremarkable. In each complex the $\left\{\mathrm{BIPM}^{\mathrm{Mes}}\right\}$ ligands are bound in a similar manner [endocyclic P-C distances ranging 1.671(12)-1.740(11) $\AA$ and P-N distances ranging 1.618(9)-1.684(9) $\AA$ ], with each adopting a pseudo-boat conformation [P-C-P angles: range: $\left.130.2(7)-134.3(7)^{\circ}\right]$. This conformation is in contrast to the $\left\{\mathrm{BIPM}^{\mathrm{TMS}}\right\}^{2-}$ ligands in $\left[\mathrm{Ln}\left(\mathrm{BIPM}^{\mathrm{TMS}}\right)\left(\mathrm{BIPM}^{\mathrm{TMS}} \mathrm{H}\right)\right]$, which exhibit near planar geometries, with P-C-P angles of $c a .166^{\circ}$ [16].

\subsection{Solution State Magnetic Properties of BIPM $M^{T M S}$ and BIPM $M^{\text {Mes }}$ Rare Earth Complexes}

The room temperature solution magnetic moments of $\mathbf{1 a}-\mathbf{c}, \mathbf{3}, \mathbf{4}, \mathbf{5} \mathbf{a}-\mathbf{b}$ and $\mathbf{7 b}$ were determined utilising the Evans method [28]. These are compiled in Table 2 along with their ground state terms and theoretical magnetic moments. The theoretical magnetic moments of rare earth complexes can be approximated by $\mu_{J}=g J V(J+1)$ [where $\left.g J=3 / 2+[S(S+1)-L(L+1)] / 2 J(J+1)\right]$ according to the Van Vleck equation for magnetic susceptibility [29], assuming the ${ }^{2 S+1} L_{J}$ ground state is well separated from excited states and crystal field splitting is negligible. This is generally true for rare earths, with the exception of $\mathrm{Sm}(\mathrm{III})$ and $\mathrm{Eu}(\mathrm{III})$, which exhibit low lying excited states of ${ }^{6} \mathrm{H}_{7 / 2}$ and ${ }^{7} \mathrm{~F}_{1}$, respectively, which each contribute to the room temperature magnetic moments [19]. As shown in Table 2 there is reasonable agreement between the theoretical and observed magnetic moments for each complex reported in this work.

Table 2. Theoretical and observed solution magnetic moments.

\begin{tabular}{ccccc}
\hline Complex & Rare earth ion & Ground state term & $\boldsymbol{\mu}_{\mathbf{J}}\left(\boldsymbol{\mu}_{\boldsymbol{B}}\right)^{\mathbf{a}}$ & $\boldsymbol{\mu}_{\text {eff }}\left(\boldsymbol{\mu}_{\mathbf{B}}\right)$ \\
\hline $\mathbf{1 a}$ & $\mathrm{Nd}(\mathrm{III})$ & ${ }^{4} \mathrm{I}_{9 / 2}$ & 3.68 & 4.14 \\
$\mathbf{1 b}$ & $\mathrm{Gd}(\mathrm{III})$ & ${ }^{8} \mathrm{~S}_{7 / 2}$ & 7.94 & 8.47 \\
$\mathbf{1 c}$ & $\mathrm{Tb}(\mathrm{III})$ & ${ }^{7} \mathrm{~F}_{6}$ & 9.72 & 9.46 \\
$\mathbf{3}$ & $\mathrm{Gd}(\mathrm{III})$ & ${ }^{8} \mathrm{~S}_{7 / 2}$ & 7.94 & 8.00 \\
$\mathbf{4}$ & $\mathrm{Yb}(\mathrm{III})$ & ${ }^{2} \mathrm{~F}_{7 / 2}$ & 4.53 & 4.29 \\
$\mathbf{5 a}$ & $\mathrm{Dy}(\mathrm{III})$ & ${ }^{6} \mathrm{H}_{15 / 2}$ & 10.63 & 9.81 \\
$\mathbf{5 b}$ & $\mathrm{Er}(\mathrm{III})$ & ${ }^{4} \mathrm{I}_{15 / 2}$ & 9.59 & 10.25 \\
$\mathbf{7 b}$ & $\mathrm{Ce}(\mathrm{III})$ & ${ }^{2} \mathrm{~F}_{5 / 2}$ & 2.54 & 1.88 \\
\hline \multicolumn{5}{c}{$\mu_{J}=g J J J(J+1)$ where $g J=3 / 2+[S(S+1)-L(L+1)] / 2 J(J+1)}$.
\end{tabular}

\section{Experimental Section}

All manipulations were carried out using standard Schlenk techniques, or an MBraun UniLab glovebox, under an atmosphere of dry nitrogen. Solvents were dried by passage through activated alumina towers and degassed before use. All solvents were stored over potassium mirrors (with the exception of THF which was stored over activated $4 \AA$ molecular sieves). Deuterated solvents were distilled from potassium, degassed by three freeze-pump-thaw cycles and stored under nitrogen. 
$\left[\mathrm{Cs}\left(\mathrm{BIPM}^{\mathrm{TMS}} \mathrm{H}\right)\right][13],\left[\mathrm{Ln}(\mathrm{I})_{3}(\mathrm{THF})_{3.5}\right](\mathrm{Ln}=\mathrm{Nd}, \mathrm{Gd}, \mathrm{Dy}, \mathrm{Er}, \mathrm{Yb})[25],\left[\left\{\mathrm{K}\left(\mathrm{BIPM}^{\mathrm{Mes}} \mathrm{H}\right)\right\}_{2}\right][6]$, $\left[\mathrm{Ln}\left(\mathrm{BIPM}^{\mathrm{Mes}} \mathrm{H}\right)(\mathrm{I})_{2}(\mathrm{THF})_{2}\right](\mathrm{Ln}=\mathrm{La}, \mathrm{Ce}, \mathrm{Pr})[12,14],\left[\mathrm{La}\left(\mathrm{BIPM}^{\mathrm{TMS}} \mathrm{H}\right)(\mathrm{I})_{2}(\mathrm{THF})\right]$ [13], and [K(Bn)] [30] were prepared according to published procedures. $\left[\mathrm{Tb}(\mathrm{I})_{3}(\mathrm{THF})_{3.5}\right]$ was prepared according to a modified literature procedure [25]. $\left[\mathrm{K}\left(\mathrm{CHPh}_{2}\right)\right]$ and $\left[\mathrm{K}\left(\mathrm{CPh}_{3}\right)\right]$ were prepared by the reaction of $\mathrm{KOBu}^{t} / \mathrm{Bu}{ }^{n} \mathrm{Li}$ with either diphenylmethane or triphenylmethane in hexanes, analogously to the preparation of $[\mathrm{K}(\mathrm{Bn})][30]$. All other materials were purchased and dried before use.

${ }^{1} \mathrm{H},{ }^{13} \mathrm{C}$ and ${ }^{31} \mathrm{P}$ NMR spectra were recorded on a Bruker 400 spectrometer operating at $400.2,100.6$ and $162.0 \mathrm{MHz}$, respectively; chemical shifts are quoted in ppm and are relative to tetramethylsilane $\left({ }^{1} \mathrm{H},{ }^{13} \mathrm{C}\right)$ or external $85 \% \mathrm{H}_{3} \mathrm{PO}_{4}\left({ }^{31} \mathrm{P}\right)$. FTIR spectra were recorded on a Bruker Tensor 27 spectrometer. Elemental microanalyses were carried out by Mr. Stephen Boyer at the Microanalysis Service, London Metropolitan University, UK.

Preparation of $\left[\mathbf{N d}\left(\mathbf{B I P M}{ }^{\mathrm{TMS}} \mathbf{H}\right)(\mathbf{I})_{2}\right.$ (THF)] (1a): THF $(40 \mathrm{~mL})$ was added to a precooled $\left(-78{ }^{\circ} \mathrm{C}\right)$ mixture of $\left[\mathrm{Cs}\left(\mathrm{BIPM}^{\mathrm{TMS}} \mathrm{H}\right)\right](0.69 \mathrm{~g}, 1.00 \mathrm{mmol})$ and $\left[\mathrm{Nd}(\mathrm{I})_{3}(\mathrm{THF})_{3.5}\right](0.78 \mathrm{~g}, 1.00 \mathrm{mmol})$ and the resulting mixture was allowed to warm to room temperature with stirring over $18 \mathrm{~h}$. The mixture was filtered to remove CsI and all volatiles were removed in vacuo to afford a pale blue solid. Recrystallisation from toluene ( $5 \mathrm{~mL}$ ) afforded $\mathbf{1 a ~} \mathrm{C}_{7} \mathrm{H}_{8}$ as pale blue crystals. Yield $0.42 \mathrm{~g}, 37 \%$. Anal. Calcd for $\mathrm{C}_{42} \mathrm{H}_{55} \mathrm{I}_{2} \mathrm{~N}_{2} \mathrm{NdOP}_{2} \mathrm{Si}_{2}$ : C, 45.05; H, 4.95; N, 2.50. Found: C, 44.89; H, 4.86; N, 2.58. FTIR v/cm ${ }^{-1}$ (Nujol): $1377(\mathrm{~m}), 1366(\mathrm{w}), 1214(\mathrm{w}), 1064(\mathrm{~m}), 992(\mathrm{w}), 839(\mathrm{~m}), 770(\mathrm{w}), 746(\mathrm{w}) . \mu_{\text {eff }}$ (Evans method, $298 \mathrm{~K}, \mathrm{C}_{6} \mathrm{D}_{6}$ ): $4.14 \mu_{\mathrm{B}}$.

Preparation of $\left[\mathbf{G d}\left(\mathbf{B I P M}{ }^{\mathrm{TMS}} \mathbf{H}\right)(\mathbf{I})_{2}\right.$ (THF)] (1b): THF $(40 \mathrm{~mL})$ was added to a precooled $\left(-78{ }^{\circ} \mathrm{C}\right)$ mixture of of $\left[\mathrm{Cs}\left(\mathrm{BIPM}^{\mathrm{TMS}} \mathrm{H}\right)\right](0.69 \mathrm{~g}, 1.00 \mathrm{mmol})$ and $\left[\mathrm{Gd}(\mathrm{I})_{3}(\mathrm{THF})_{3.5}\right](0.79 \mathrm{~g}, 1.00 \mathrm{mmol})$ and the resulting mixture was allowed to warm to room temperature with stirring over $18 \mathrm{~h}$. The mixture was filtered to remove CsI and the solution reduced in volume to $c a .5 \mathrm{~mL}$. Cooling of the solution to $-30{ }^{\circ} \mathrm{C}$ afforded $\mathbf{1 b} \quad \mathrm{OC}_{4} \mathrm{H}_{8}$ as yellow crystals. Yield $0.56 \mathrm{~g}, 50 \%$. Anal. Calcd for $\mathrm{C}_{39} \mathrm{H}_{55} \mathrm{GdI}_{2} \mathrm{~N}_{2} \mathrm{O}_{2} \mathrm{P}_{2} \mathrm{Si}_{2}$ : C, 42.09; H, 4.98; N, 2.52. Found: C, 42.07; H, 4.95; N, 2.61. FTIR v/cm ${ }^{-1}$ (Nujol): 1437 (m), 1152 (m), 1114 (s), 1057 (s), 920 (w), 839 (m), 752 (w), 745 (w), 725 (w), 712 (w), $695(\mathrm{w}), 660(\mathrm{w}), 551(\mathrm{~m}), 504(\mathrm{w}) . \mu_{\text {eff }}$ (Evans method, $298 \mathrm{~K}, \mathrm{C}_{6} \mathrm{D}_{6}$ ): $8.47 \mu_{\mathrm{B}}$.

Preparation of $\left[\mathbf{T b}\left(\mathbf{B I P M} \mathbf{M}^{\mathrm{TMS}} \mathbf{H}\right)(\mathbf{I})_{2}\right.$ (THF)] (1c): THF $(40 \mathrm{~mL})$ was added to a precooled $\left(-78{ }^{\circ} \mathrm{C}\right)$ mixture of $\left[\mathrm{Tb}(\mathrm{I})_{3}(\mathrm{THF})_{3.5}\right](0.79 \mathrm{~g}, 1.00 \mathrm{mmol})$ and $\left[\mathrm{Cs}\left(\mathrm{BIPM}^{\mathrm{TMS}} \mathrm{H}\right)\right](0.69 \mathrm{~g}, 1.00 \mathrm{mmol})$ and the resulting mixture was allowed to warm to room temperature with stirring over $18 \mathrm{~h}$. The mixture was filtered to remove CsI and the resulting solution reduced in volume to $c a .5 \mathrm{~mL}$. Cooling of the solution to $4{ }^{\circ} \mathrm{C}$ afforded $1 \mathrm{c} \mathrm{OC}_{4} \mathrm{H}_{8}$ as yellow crystals. Yield $0.38 \mathrm{~g}, 34 \%$. Anal. Calcd for $\mathrm{C}_{39} \mathrm{H}_{55} \mathrm{I}_{2} \mathrm{~N}_{2} \mathrm{O}_{2} \mathrm{P}_{2} \mathrm{Si}_{2} \mathrm{~Tb}: \mathrm{C}, 42.02 ; \mathrm{H}, 4.97 ; \mathrm{N}, 2.51$. Found: C, 41.92; H, 4.88; N, 2.62. FTIR v/cm ${ }^{-1}$ (Nujol): 1437 (m), 1154 (m), 1114 (m), 1056 (m), 938 (w), 920 (w), 840 (m), 771 (m), 753 (w), 725 $(\mathrm{w}), 712(\mathrm{w}), 695(\mathrm{w}), 551(\mathrm{~m}) \cdot \mu_{\text {eff }}$ (Evans method, $298 \mathrm{~K}, \mathrm{C}_{6} \mathrm{D}_{6}$ ): $9.46 \mu_{\mathrm{B}}$.

Preparation of $\left[\left\{\mathbf{L a}\left(\mathbf{B I P M}{ }^{\mathrm{TMS}} \mathbf{H}\right)(\mathbf{I})\left(\mu_{-} \mathbf{I}\right)\right\}_{2}\right]$ (2): During our studies we prepared many samples of $\left[\mathrm{La}\left(\mathrm{BIPM}^{\mathrm{TMS}} \mathrm{H}\right)(\mathrm{I})_{2}(\mathrm{THF})\right]$, and on one occasion, following routine workup and recrystallisation, isolated a crop of crystals of $22 \mathrm{C}_{7} \mathrm{H}_{8}$ suitable for single crystal X-ray diffraction studies. Anal. Calcd for $\mathrm{C}_{76} \mathrm{H}_{94} \mathrm{I}_{4} \mathrm{La}_{2} \mathrm{~N}_{4} \mathrm{P}_{4} \mathrm{Si}_{4}: \mathrm{C}, 43.78 ; \mathrm{H}, 4.54 ; \mathrm{N}, 2.69$. Found: C, 43.77; H, 4.49; N, 2.53. FTIR v/cm ${ }^{-1}$ (Nujol): 3054 (w), 1438 (m), 1415 (w), 1261 (m), 1214 (w), 1181 (w), 1116 (m), 1070 (m), 991 (m), 
$839(\mathrm{~m}), 770(\mathrm{~m}), 745(\mathrm{~m}), 695(\mathrm{~m}) 407(\mathrm{~m})$. The low solubility of 2 in arene solvents precluded NMR spectroscopy being performed in $d_{6}$-benzene or $d_{8}$-toluene, while dissolution in donor solvents such as $d_{8}$-THF afforded the solvated complex [La(BIPM $\left.\left.{ }^{\mathrm{TMS}} \mathrm{H}\right)(\mathrm{I})_{2}\left(d_{8}-\mathrm{THF}\right)\right][13]$.

Preparation of $\left.\left[\mathbf{G d}\left(\mathbf{B I P M}^{\mathrm{Mes}} \mathbf{H}\right)(\mathbf{I})_{2} \text { (THF) }\right)_{2}\right](3)$ : THF $(40 \mathrm{~mL})$ was added to a precooled $\left(-78{ }^{\circ} \mathrm{C}\right)$ mixture of $\left[\left\{\mathrm{K}\left(\mathrm{BIPM}^{\mathrm{Mes}} \mathrm{H}\right)\right\}_{2}\right](0.69 \mathrm{~g}, 0.50 \mathrm{mmol})$ and $\left[\mathrm{Gd}(\mathrm{I})_{3}(\mathrm{THF})_{3.5}\right](0.79 \mathrm{~g}, 1.00 \mathrm{mmol})$ and the resulting mixture was raised to room temperature with stirring over $18 \mathrm{~h}$. The mixture was filtered to remove $\mathrm{KI}$ and all volatiles were removed in vacuo to afford a yellow solid. Recrystallisation from hot toluene $\left(3 \mathrm{ml}\right.$ ) afforded $3 \mathrm{a} 3 \mathrm{C}_{7} \mathrm{H}_{8}$ as yellow crystals on cooling to $4{ }^{\circ} \mathrm{C}$. Yield $0.72 \mathrm{~g}, 49 \%$. Anal. Calcd for $\mathrm{C}_{72} \mathrm{H}_{83} \mathrm{GdI}_{2} \mathrm{~N}_{2} \mathrm{O}_{2} \mathrm{P}_{2}$ : C, 58.37; H, 5.65; N, 1.89. Found: C, 58.17; H, 5.57; N, 1.74. FTIR v/cm ${ }^{-1}$ (Nujol): 1435 (m), 1213 (m), 1155 (m), 940 (w), 854 (m), 741 (m), 695 (m), 663 (w), 590 (w), 560 $(\mathrm{w}), 535(\mathrm{~m}) . \mu_{\text {eff }}$ (Evans method, $\left.298 \mathrm{~K}, \mathrm{C}_{6} \mathrm{D}_{6}\right): 8.00 \mu_{\mathrm{B}}$.

Preparation of $\left[\mathbf{Y b}\left(\mathbf{B I P M} \mathbf{M}^{\mathrm{Mes}} \mathbf{H}\right)(\mathbf{I})_{2}\right.$ (THF)] (4):THF $(40 \mathrm{~mL})$ was added to a precooled $\left(-78{ }^{\circ} \mathrm{C}\right)$ mixture of $\left[\mathrm{Yb}(\mathrm{I})_{3}(\mathrm{THF})_{3.5}\right](1.21 \mathrm{~g}, 1.50 \mathrm{mmol})$ and $\left[\left\{\mathrm{K}\left(\mathrm{BIPM}^{\mathrm{Mes}} \mathrm{H}\right)\right\}_{2}\right](1.05 \mathrm{~g}, 0.75 \mathrm{mmol})$, and the resulting orange mixture was raised to room temperature with stirring over $18 \mathrm{~h}$. The mixture was filtered to remove $\mathrm{KI}$ and all volatiles removed in vacuo to afford an orange solid. Recrystallisation from hot toluene $(15 \mathrm{ml})$ afforded $43 \mathrm{C}_{7} \mathrm{H}_{8}$ as orange crystals on cooling to $-30{ }^{\circ} \mathrm{C}$. Yield $0.55 \mathrm{~g}, 26 \%$. Anal. Calcd for $\mathrm{C}_{47} \mathrm{H}_{51} \mathrm{I}_{2} \mathrm{~N}_{2} \mathrm{OP}_{2} \mathrm{Yb}$ : C, 49.14; H, 4.48; N, 2.44. found: C, 49.34; H, 4.58; N, 2.10. FTIR v/cm ${ }^{-1}$ (Nujol): 1588 (w), 1302 (w), 1261 (m), 1214 (m), 1156 (m), 1106 (s), 1014 (s), 859 (w), 792 (w), $771(\mathrm{~m}), 733(\mathrm{~m}), 588(\mathrm{w}), 572(\mathrm{w}), 536(\mathrm{w}) . \mu_{\text {eff }}$ (Evans method, $\left.298 \mathrm{~K}, \mathrm{THF}\right): 4.29 \mu_{\mathrm{B} .}$

Preparation of [Dy(BIPM $\left.\left.{ }^{\mathrm{Mes}} \mathbf{H}\right)_{2}\right]\left[\mathbf{B I P M} \mathbf{M e s}^{\mathrm{Mes}} \mathbf{H}\right](\mathbf{5 a})$ : THF $(20 \mathrm{~mL})$ was added to a precooled $\left(-78^{\circ} \mathrm{C}\right)$ mixture of $\left[\left\{\mathrm{K}\left(\mathrm{BIPM}^{\mathrm{Mes}} \mathrm{H}\right)\right\}_{2}\right](0.69 \mathrm{~g}, 0.50 \mathrm{mmol})$ and $\left[\mathrm{Dy}(\mathrm{I})_{3}(\mathrm{THF})_{3.5}\right](0.80 \mathrm{~g}, 1.00 \mathrm{mmol})$ and the resulting mixture was allowed to raise to room temperature with stirring over $18 \mathrm{~h}$. The mixture was filtered to remove $\mathrm{KI}$ and volatiles removed in vacuo to yield a pale yellow solid. Recrystallisation from a hot toluene solution $\left(3 \mathrm{ml}\right.$ ) afforded $5 \mathbf{a} 4 \mathrm{C}_{7} \mathrm{H}_{8}$ as yellow crystals on cooling to ambient temperature. Yield 0.32 g, 39\%. Anal. Calcd for $\mathrm{C}_{157} \mathrm{H}_{161} \mathrm{DyN}_{6} \mathrm{P}_{6}$ : C, 76.03; H, 6.54; N, 3.39. Found: C, 69.03; H, 6.72; N, 3.58. Despite repeated attempts more satisfactory elemental analyses could not be obtained, with the low carbon value ascribed to carbide formation [31] causing incomplete combustion during analysis. FTIR v/cm ${ }^{-1}$ (Nujol): 1604 (w), 1587 (w), 1573 (w), 1435 (m), 1332 (w), $1208(\mathrm{~m}), 1154(\mathrm{w}), 972(\mathrm{w}), 940(\mathrm{w}), 853$ (w) 739 (m), $694(\mathrm{~m}) . \mu_{\mathrm{eff}}$ (Evans method, $298 \mathrm{~K}, \mathrm{C}_{6} \mathrm{D}_{6}$ ): $9.81 \mu_{\mathrm{B}}$.

Preparation of $\left[\operatorname{Er}\left(\mathbf{B I P M}^{\mathrm{Mes}} \mathbf{H}\right)_{2}\right]\left[\mathbf{B I P M}^{\mathrm{Mes}} \mathbf{H}\right](\mathbf{5 b})$ : THF $(20 \mathrm{~mL})$ was added to a precooled $\left(-78^{\circ} \mathrm{C}\right)$ mixture of $\left[\operatorname{Er}(\mathrm{I})_{3}(\mathrm{THF})_{3.5}\right](1.20 \mathrm{~g}, 1.50 \mathrm{mmol})$ and $\left.\left[\left\{\mathrm{K}_{(\mathrm{BIPM}}{ }^{\mathrm{Mes}} \mathrm{H}\right)\right\}_{2}\right](1.05 \mathrm{~g}, 0.75 \mathrm{mmol})$, and the resultant beige mixture allowed to raise to room temperature with stirring over $72 \mathrm{~h}$. The resulting suspension was filtered and volatiles were removed in vacuo to afford a pink solid. The solid was washed with hexanes and recrystallised from hot toluene $(15 \mathrm{~mL})$ to afford $\mathbf{5 b} 5 \mathrm{C}_{7} \mathrm{H}_{8}$ as pale yellow crystals on cooling to $-30{ }^{\circ} \mathrm{C}$. Yield $0.40 \mathrm{~g}, 31 \%$. Anal. Calcd for $\mathrm{C}_{164} \mathrm{H}_{16}{ } \mathrm{ErN}_{6} \mathrm{P}_{6}$ : C, 76.43; H, 6.61; N, 3.26. Found: C, 76.32: H, 6.48: N, 3.37. FTIR v/cm ${ }^{-1}$ (Nujol): 1261 (s), 1205 (w), 1098 (s), 1020 (s), $971(\mathrm{w}), 853(\mathrm{w}), 800(\mathrm{~s}), 694(\mathrm{~m}), 525$ (m). $\mu_{\text {eff }}$ (Evans method, $\left.298 \mathrm{~K}, \mathrm{THF}\right): 10.25 \mu_{\mathrm{B}}$.

Preparation of $\left[\mathrm{La}\left(\mathrm{BIPM}^{\mathrm{Mes}} \mathrm{H}\right)(\mathrm{I})_{2}\right.$ (TMEDA)] (6a) and $\left[\mathrm{Gd}\left(\mathrm{BIPM}^{\mathrm{Mes}} \mathrm{H}\right)(\mathrm{I})_{2}\right.$ (TMEDA)] (6b): Complexes $\mathbf{6 a}$ and $\mathbf{6 b}$ were prepared by the dissolution of $\left[\operatorname{Ln}\left(\mathrm{BIPM}^{\mathrm{Mes}} \mathrm{H}\right)(\mathrm{I})_{2}(\mathrm{THF})\right](\mathrm{Ln}=\mathrm{La}, \mathrm{Gd})$ in 
a THF/TMEDA solution followed by stirring for $18 \mathrm{~h}$. In each case all volatiles were removed in vacuo to afford $\mathbf{6 a}(\mathrm{Ln}=\mathrm{La})$ or $\mathbf{6 b}(\mathrm{Ln}=\mathrm{Gd})$ as off-white and yellow solids, respectively, in quantitative yield. Recrystallisation of a small portion of each sample from toluene afforded crops of crystals of $\mathbf{6 a} 3 \mathrm{C}_{7} \mathrm{H}_{8}$ and $\mathbf{6 b} 2 \mathrm{C}_{7} \mathrm{H}_{8}$, respectively, suitable for single crystal X-ray diffraction studies. Data for $6 \mathbf{a} 3 \mathrm{C}_{7} \mathrm{H}_{8}$ : Anal. Calcd for $\mathrm{C}_{70} \mathrm{H}_{83} \mathrm{I}_{2} \mathrm{LaN}_{4} \mathrm{P}_{2}$ : C, 58.59; H, 5.83; N, 3.90. Found: C, 58.47; H, 5.93; N, 4.02. ${ }^{1} \mathrm{H}$ NMR $\left(298 \mathrm{~K}, \mathrm{C}_{6} \mathrm{D}_{6}\right): 1.65-2.40$ (34 H, m, br, Mes-CH $\left.\mathrm{H}_{3}, \mathrm{NCH}_{2}, \mathrm{NCH}_{3}\right), 3.91(1 \mathrm{H}, \mathrm{t}$, $\left.{ }^{2} J_{\mathrm{PH}}=8.8 \mathrm{~Hz}, H \mathrm{CP}_{2}\right), 6.55-7.15(24 \mathrm{H}, \mathrm{m}, \mathrm{br}, \mathrm{Ar}-H) .{ }^{13} \mathrm{C}\left\{{ }^{1} \mathrm{H}\right\} \mathrm{NMR}\left(298 \mathrm{~K}, \mathrm{C}_{6} \mathrm{D}_{6}\right): 8.44\left(C \mathrm{H}, \mathrm{t}, J_{\mathrm{PC}}\right.$ $=138 \mathrm{~Hz}, \mathrm{HCP} 2), 20.51\left(\mathrm{Mes}-\mathrm{CH}_{3}\right), 20.65\left(\mathrm{Mes}-\mathrm{CH}_{3}\right), 21.18\left(\mathrm{Mes}-\mathrm{CH}_{3}\right), 21.44\left(\mathrm{Mes}-\mathrm{CH}_{3}\right), 49.84$ $\left(\mathrm{NCH}_{3}\right), 57.87\left(\mathrm{NCH}_{2}\right), 125.44(\mathrm{Ar}-\mathrm{CH}), 125.82(\mathrm{Ar}-\mathrm{C}), 129.08(\mathrm{Ar}-\mathrm{CH}), 129.81(\mathrm{Ar}-\mathrm{CH}), 130.61$ $(\mathrm{Ar}-\mathrm{CH}), 131.11(\mathrm{Ar}-\mathrm{CH}), 131.31$ (Ar- $\mathrm{CH}), 132.17$ (Ar-C), 132.58 (Ar- $\mathrm{CH}), 135.53$ (Ar-C), 137.64 (Ar-C), $142.50(\operatorname{Ar}-C) .{ }^{31} \mathrm{P}\left\{{ }^{1} \mathrm{H}\right\}$ NMR (298 K, $\left.\mathrm{C}_{6} \mathrm{D}_{6}\right): 15.70$ (s). FTIR v/cm ${ }^{-1}$ (Nujol): 3053 (w), 1436 (m), $1215(\mathrm{~m}), 1158(\mathrm{~m}), 401$ (m). As full spectroscopic data supported the formulation of $\mathbf{6 a}$, full spectroscopic data was not obtained for paramagnetic $\mathbf{6 b}$ which was subsequently prepared and utilised in situ. During our investigations we attempted many preparations of [ $\left[\mathrm{Ln}\left(\mathrm{BIPM}^{\mathrm{Mes}}\right)(\mathrm{I})(\mathrm{THF})_{n}\right]$ $(\mathrm{Ln}=\mathrm{La}, \mathrm{Ce}, \mathrm{Pr}, \mathrm{Gd})$ utilising a range of methanide precursors including $\left[\mathrm{Ln}\left(\mathrm{BIPM}^{\mathrm{Mes}}\right)(\mathrm{I})_{2}(\mathrm{THF})_{2}\right]$ $(\mathrm{Ln}=\mathrm{La}, \mathrm{Ce}, \mathrm{Pr}, \mathrm{Gd})$ and $\left[\mathrm{Ln}\left(\mathrm{BIPM}^{\mathrm{Mes}}\right)(\mathrm{I})_{2}(\mathrm{TMEDA})\right](\mathrm{Ln}=\mathrm{La}, \mathbf{6 a} ; \mathrm{Gd}, 6 \mathbf{6})$ and bases including $[\mathrm{K}(\mathrm{Bn})],\left[\mathrm{K}\left\{\mathrm{CHPh}_{2}\right\}\right]$ and $\left[\mathrm{K}\left\{\mathrm{C}(\mathrm{Ph})_{3}\right\}\right]$. In each case $\left[\mathrm{Ln}\left(\mathrm{BIPM}^{\mathrm{Mes}}\right)(\mathrm{I})(\mathrm{THF})_{n}\right]$ was not isolated cleanly with mixtures of products observed in each case. The sole isolable products from these reactions were $\left[\mathrm{Ln}\left(\mathrm{BIPM}^{\mathrm{Mes}} \mathrm{H}\right)\left(\mathrm{BIPM}^{\mathrm{Mes}}\right)\right](\mathrm{Ln}=\mathrm{La}, \mathbf{7} \mathbf{a} ; \mathrm{Ce}, \mathbf{7 b} ; \mathrm{Pr}, 7 \mathbf{c} ; \mathrm{Gd}, \mathbf{7 d})$, with representative preparations of $7 \mathbf{a}$ and $7 \mathbf{b}$ given below.

Preparation of [La(BIPM $\left.\left.{ }^{\text {Mes }} \mathbf{H}\right)\left(\mathbf{B I P M} \mathbf{M}^{\text {Mes }}\right)\right](\mathbf{7 a})$ : THF $(15 \mathrm{~mL})$ was added to a pre-cooled $\left(-78{ }^{\circ} \mathrm{C}\right)$ mixture of $\left[\mathrm{La}\left(\mathrm{BIPM}^{\mathrm{Mes}} \mathrm{H}\right)(\mathrm{I})_{2}(\mathrm{THF})\right]$ 3toluene $(0.71 \mathrm{~g}, 0.49 \mathrm{mmol})$ and $\left[\mathrm{K}\left(\mathrm{CHPh}_{2}\right)\right](0.10 \mathrm{~g}, 0.49 \mathrm{mmol})$. The resulting orange suspension was stirred at this temperature for $10 \mathrm{~m}$ and then raised to room temperature with stirring over $18 \mathrm{~h}$. The resulting deep brown suspension was filtered to remove KI and all volatiles removed in vacuo to afford a brown solid. Recrystallisation from toluene (4 $\mathrm{mL})$ afforded colourless crystals of $7 \mathbf{a} 3 \mathrm{C}_{7} \mathrm{H}_{8}$. Yield $70 \mathrm{mg}, 8 \%$. Anal. Calcd for $\mathrm{C}_{107} \mathrm{H}_{109} \mathrm{LaN}_{4} \mathrm{P}_{4}$ : C, 74.99; $\mathrm{H}, 6.41$; N, 3.27. Found: C, 74.77; H, 6.78; N, 3.17. ${ }^{1} \mathrm{H}$ NMR ( $d_{6}$-benzene, $\left.298 \mathrm{~K}\right): \delta 2.10(12 \mathrm{H}$, s, br, $o$-Mes-CH $\left.\mathrm{CH}_{3}\right), 2.26\left(1 \mathrm{H}, \mathrm{s}, \mathrm{HCP}_{2}\right), 2.37(12 \mathrm{H}, \mathrm{s}, \mathrm{br}, o$-Mes-CH$), 2.46\left(6 \mathrm{H}, \mathrm{s}, p\right.$-Mes-CH $\left.\mathrm{CH}_{3}\right), 2.57(6 \mathrm{H}$, s, $p$-Mes- $\left.\mathrm{CH}_{3}\right)$, 6.6-7.1 (28 H, m, br, Ar-CH), 7.37 (8 H, s, br, Ar-CH), 7.6-7.9 (12 H, m, br, Ar-CH). ${ }^{13} \mathrm{C}\left\{{ }^{1} \mathrm{H}\right\}$ NMR $\left(d_{6}\right.$-benzene, $\left.298 \mathrm{~K}\right): \delta 4.59\left(\mathrm{t}, J_{\mathrm{PC}}=127 \mathrm{~Hz}, \mathrm{HCP} 2\right), 20.67\left(\mathrm{Mes}-C_{3}\right), 20.83\left(\mathrm{Mes}-\mathrm{CH}_{3}\right)$, $21.20\left(\mathrm{Mes}-\mathrm{CH}_{3}\right), 22.80\left(\mathrm{Mes}-\mathrm{CH}_{3}\right), 45.06\left(\mathrm{~s}, \mathrm{CP}_{2}\right), 125.45(\mathrm{Ar}-\mathrm{C}), 126.09(\mathrm{Ar}-\mathrm{C}), 126.75(\mathrm{Ar}-\mathrm{CH})$, 128.09 (m, Ar-CH), $129.03(\mathrm{Ar}-\mathrm{CH}), 129.64(\mathrm{Ar}-\mathrm{CH}), 130.34(\mathrm{Ar}-\mathrm{CH}), 130.57(\mathrm{Ar}-\mathrm{CH}), 131.12(\mathrm{Ar}-\mathrm{CH})$, 132.17 (Ar-CH), $134.54(\mathrm{Ar}-C), 135.18$ (br, Ar-C), 137.65 (Ar-C), 143.07 (Ar-C). ${ }^{31} \mathrm{P}\left\{{ }^{1} \mathrm{H}\right\} \mathrm{NMR}\left(d_{6}\right.$-benzene, $298 \mathrm{~K}): 2.88\left(\mathrm{CP}_{2}\right), 10.51\left(\mathrm{HCP}_{2}\right)$. FTIR v/cm-1 (Nujol): 1589 (w), 1261 (s), 1098 (s), 1020 (s), $854(\mathrm{w}), 800(\mathrm{~s}), 663(\mathrm{~m})$.

Preparation of $\left[\mathbf{C e}\left(\mathbf{B I P M}{ }^{\mathrm{Mes}} \mathbf{H}\right)\left(\mathrm{BIPM}^{\mathrm{Mes}}\right)\right] \mathbf{( 7 b )}$ : THF $(25 \mathrm{~mL})$ was added to a pre-cooled $\left(-78{ }^{\circ} \mathrm{C}\right)$ mixture of $\left[\mathrm{Ce}\left(\mathrm{BIPM}^{\mathrm{Mes}} \mathrm{H}\right)(\mathrm{I})_{2}(\mathrm{THF})\right](3.00 \mathrm{~g}, 2.54 \mathrm{mmol})$ and $[\mathrm{K}(\mathrm{Bn})](0.33 \mathrm{~g}, 2.54 \mathrm{mmol})$ and the resulting mixture allowed to warm to room temperature with stirring over $20 \mathrm{~h}$. The resulting mixture was filtered and all volatiles removed in vacuo to afford a brown solid. The solid was washed with hexanes and the resulting brown powder was recrystallised from toluene $(5 \mathrm{~mL})$ to afford $7 \mathbf{b} 3 \mathrm{C}_{7} \mathrm{H}_{8}$ as yellow crystals, as identified by unit cell check [32]. Yield $0.10 \mathrm{~g}, 3 \%$. On standing, the hexanes 
extract yielded $\mathbf{7 b} 2 \mathrm{C}_{6} \mathrm{H}_{14}$ as yellow crystals suitable for single crystal X-ray diffraction studies. Yield 0.14 g, 4\%. Anal. Calcd for $\mathrm{C}_{86} \mathrm{H}_{85} \mathrm{CeN}_{4} \mathrm{P}_{4}: \mathrm{C}, 71.80 ; \mathrm{H}, 5.96 ; \mathrm{N}, 3.89$. Found: C, 71.67; H, 5.88; N, 3.79. FTIR v/cm-1 (Nujol): 1261 (m), 1212 (m), 1153 (m), 1099 (s), 1019 (s), 800 (s), 721 (w), 694 (w), $519(\mathrm{w}) . \mu_{\mathrm{eff}}($ Evans method, $298 \mathrm{~K}, \mathrm{THF}): 1.88 \mu_{\mathrm{B}}$.

\section{X-ray Crystallography}

Crystal data for compounds $\mathbf{1 - 7 d}$ are given in Table S2. Bond lengths and angles are listed in Table S1. Crystals were examined variously on a Bruker APEX CCD area detector diffractometer using graphite-monochromated MoK $\alpha$ radiation $(\lambda=0.71073 \AA)$, or on an Oxford Diffraction SuperNova Atlas $\mathrm{CCD}$ diffractometer using mirror-monochromated $\mathrm{CuK} \alpha$ radiation $(\lambda=1.5418 \AA)$. Intensities were integrated from data recorded on 0.3 (APEX) or $1^{\circ}$ (SuperNova) frames by $\omega$ rotation. Cell parameters were refined from the observed positions of all strong reflections in each data set. Semi-empirical absorption correction based on symmetry-equivalent and repeat reflections (APEX) or Gaussian grid face-indexed absorption correction with a beam profile correction (Supernova), were applied. The structures were solved variously by direct and heavy atom methods and were refined by full-matrix least-squares on all unique $F^{2}$ values, with anisotropic displacement parameters for all non-hydrogen atoms, and with constrained riding hydrogen geometries; $U_{\text {iso }}(\mathrm{H})$ was set at 1.2 (1.5 for methyl groups) times $U_{\text {eq }}$ of the parent atom. The largest features in final difference syntheses were close to heavy atoms and were of no chemical significance. The data-set obtained for $\mathbf{4}$ is of low quality, and while the connectivity is clear, no assessment could be made of the geometric parameters, and despite exhaustive attempts, a better data-set could not be obtained. Highly disordered solvent molecules of crystallisation in $\mathbf{4}$ and $\mathbf{7 a - d}$ could not be modelled and were treated with the Platon SQUEEZE procedure [33]. Programs were Bruker AXS SMART [34] and CrysAlisPro (control) [35], Bruker AXS SAINT [34] and CrysAlisPro (integration) [35], and SHELXTL [36] and OLEX2 [37] were employed for structure solution and refinement and for molecular graphics. Crystal data have been deposited with the Cambridge Structural Database CCDC numbers 970500-970513.

\section{Conclusions}

We have successfully extended the series of $\left\{\mathrm{BIPM}^{\mathrm{TMS}} \mathrm{H}\right\}^{-}$derived rare earth methanides by the preparation of $\left[\mathrm{Ln}\left(\mathrm{BIPM}^{\mathrm{TMS}} \mathrm{H}\right)(\mathrm{I})_{2}(\mathrm{THF})\right](\mathrm{Ln}=\mathrm{Nd}, \mathrm{Gd}, \mathrm{Tb}), \mathbf{1 a}-\mathbf{c}$, in moderate to good yields. Similarly, we have successfully extended the range of $\left\{\mathrm{BIPM}^{\mathrm{Mes}} \mathrm{H}\right\}^{-}$derived rare earth methanides with the preparation of $\left[\mathrm{Gd}\left(\mathrm{BIPM}^{\mathrm{Mes}} \mathrm{H}\right)(\mathrm{I})_{2}(\mathrm{THF})_{2}\right], \mathbf{3}$, and $\left[\mathrm{Yb}\left(\mathrm{BIPM}^{\mathrm{Mes}} \mathrm{H}\right)(\mathrm{I})_{2}(\mathrm{THF})\right], \mathbf{4}$, but solubility issues of $\left[\mathrm{Ln}(\mathrm{I})_{3}(\mathrm{THF})_{3.5}\right]$ prevented the preparation of dysprosium and erbium analogues, with $\left[\operatorname{Ln}\left(\mathrm{BIPM}^{\mathrm{Mes}} \mathrm{H}\right)_{2}\right]\left[\left(\mathrm{BIPM}^{\mathrm{Mes}} \mathrm{H}\right)\right],(\mathrm{Ln}=\mathrm{Dy}, \mathbf{5 a} ; \mathrm{Er}, \mathbf{5 b})$ being the only isolable products of these reactions. Dissolution of $\left[\mathrm{Ln}\left(\mathrm{BIPM}^{\mathrm{Mes}} \mathrm{H}\right)(\mathrm{I})_{2}(\mathrm{THF})\right](\mathrm{Ln}=\mathrm{La}, \mathrm{Gd})$ in a TMEDA/THF solution afforded the TMEDA adduct complexes $\left[\mathrm{Ln}\left(\mathrm{BIPM}^{\mathrm{Mes}} \mathrm{H}\right)(\mathrm{I})_{2}(\mathrm{TMEDA})\right](\mathrm{Ln}=\mathrm{La}, \mathbf{6 a} ; \mathrm{Gd}, \mathbf{6 b})$ in essentially quantitative yields. Attempts to prepare $\left[\mathrm{La}\left(\mathrm{BIPM}^{\mathrm{Mes}}\right)(\mathrm{I})(\mathrm{S}) n\right]$ and other rare earth analogues were not successful, with the reactions of $\left[\operatorname{Ln}\left(\mathrm{BIPM}^{\mathrm{Mes}} \mathrm{H}\right)(\mathrm{I})_{2}(\mathrm{~S})\right](\mathrm{Ln}=\mathrm{La}, \mathrm{Ce}, \mathrm{Pr}, \mathrm{Gd} ; \mathrm{S}=$ THF or TMEDA) with a range of bases yielding mixtures of products, of which, only $\left[\operatorname{Ln}\left(\mathrm{BIPM}^{\mathrm{Mes}}\right)\left(\mathrm{BIPM}^{\mathrm{Mes}} \mathrm{H}\right)\right](\mathrm{Ln}=\mathrm{La}, \mathbf{7 a} ; \mathrm{Ce}, \mathbf{7 b} ; \mathrm{Pr}, \mathbf{7 c} ; \mathrm{Gd}, \mathbf{7 d})$ could be identified. 


\section{Acknowledgments}

We thank the Royal Society for a University Research Fellowship (S.T.L.), and the EPSRC, European Research Council, and the University of Nottingham for generously supporting this work.

\section{Conflicts of Interest}

The authors declare no conflict of interest.

\section{References and Notes}

1. Aparna, K.; Ferguson, M.; Cavell, R.G. A Monomeric Samarium Bis(Iminophosphorano) Chelate Complex with a $\mathrm{Sm}=\mathrm{C}$ Bond. J. Am. Chem. Soc. 2000, 122, 726-727.

2. Liddle, S.T.; Mills, D.P.; Wooles, A.J. Bis(phosphorus-stabilized)methanide and methandiide derivatives of Group 1-5 and f-element metals. Organomet. Chem. 2010, 36, 29-55.

3. Liddle, S.T.; Mills, D.P.; Wooles, A.J. Early metal bis(phosphorus-stabilized)carbene chemistry. Chem. Soc. Rev. 2011, 40, 2164-2176.

4. Roesky, P.W. Bis(phosphinimino)methanides as ligands in the chemistry of the rare earth elements. Z. Anorg. Allg. Chem. 2006, 632, 1918-1926.

5. Rastätter, M.; Zulys, A.; Roesky, P.W. A bis(phosphinimino)methanide lanthanum amide as catalyst for the hydroamination/cyclisation, hydrosilylation and sequential hydroamination/hydrosilylation catalysis. Chem. Commun. 2006, 874-876.

6. Ahmed, S.A.; Hill, M.S.; Hitchcock, P.B. Synthesis and M-C $\gamma$ Hemilability of Group 2 Bis(phosphinimino)methanides. Organometallics 2006, 25, 394-402.

7. Liddle, S.T.; Mills, D.P.; Gardner, B.M.; McMaster, J.; Jones, C.; Woodul, W.D. A Heterobimetallic Gallyl Complex Containing an Unsupported Ga-Y Bond. Inorg. Chem. 2009, 48, 3520-3522.

8. Mills, D.P.; Soutar, L.; Lewis, W.; Blake, A.J.; Liddle, S.T. Regioselective C-H Activation and Sequential C-C and C-O Bond Formation Reactions of Aryl Ketones Promoted by an Yttrium Carbene. J. Am. Chem. Soc. 2010, 132, 14379-14381.

9. Mills, D.P.; Soutar, L.; Cooper, O.J.; Lewis, W.; Blake, A.J.; Liddle, S.T. Reactivity of the Yttrium Alkyl Carbene Complex $\left[\mathrm{Y}(\mathrm{BIPM})\left(\mathrm{CH}_{2} \mathrm{C}_{6} \mathrm{H}_{5}\right)(\mathrm{THF})\right]\left(\mathrm{BIPM}=\left\{\mathrm{C}\left(\mathrm{PPh}_{2} \mathrm{NSiMe}_{3}\right)_{2}\right\}\right)^{2-}$ : From Insertions, Substitutions, and Additions to Nontypical Transformations. Organometallics 2013, 32, 1251-1264.

10. Mills, D.P.; Lewis, W.; Blake, A.J.; Liddle, S.T. Reactivity Studies of a T-Shaped Yttrium Carbene: $\mathrm{C}-\mathrm{F}$ and $\mathrm{C}-\mathrm{O}$ Bond Activation and $\mathrm{C}=\mathrm{C}$ Bond Formation Promoted by $\left[\mathrm{Y}(\mathrm{BIPM})(\mathrm{I})(\mathrm{THF})_{2}\right]\left(\mathrm{BIPM}=\mathrm{C}\left(\mathrm{PPh}_{2} \mathrm{NSiMe}_{3}\right)_{2}\right)$. Organometallics 2013, 32, 1239-1250.

11. Gregson, M.; Lu, E.; McMaster, J.; Lewis, W.; Blake, A.J.; Liddle, S.T. A Cerium(IV)-Carbon Multiple Bond. Angew. Chem. Int. Ed. 2013, 52, 13016-13019.

12. Wooles, A.J.; Cooper, O.J.; McMaster, J.; Lewis, W.; Blake, A.J.; Liddle, S.T. Synthesis and Characterization of Dysprosium and Lanthanum Bis(iminophosphorano)methanide and -methanediide Complexes. Organometallics 2010, 29, 2315-2321. 
13. Wooles, A.J.; Gregson, M.; Cooper, O.J.; Middleton-Gear, A.; Mills, D.P.; Lewis, W.; Blake, A.J.; Liddle, S.T. Group 1 Bis(iminophosphorano)methanides, Part 1: N-Alkyl and Silyl Derivatives of the Sterically Demanding Methanes $\mathrm{H}_{2} \mathrm{C}\left(\mathrm{PPh}_{2} \mathrm{NR}\right)_{2}(\mathrm{R}=$ Adamantyl and Trimethylsilyl). Organometallics 2011, 30, 5314-5325.

14. Wooles, A.J.; Gregson, M.; Robinson, S.; Cooper, O.J.; Mills, D.P.; Lewis, W.; Blake, A.J.; Liddle, S.T. Group 1 Bis(iminophosphorano)methanides, Part 2: $N$-Aryl Derivatives of the Sterically Demanding Methanes $\mathrm{H}_{2} \mathrm{C}\left(\mathrm{PPh}_{2} \mathrm{NR}\right)_{2}$ ( $\mathrm{R}=$ 2,4,6-trimethylphenyl or 2,6-diisopropylphenyl). Organometallics 2011, 30, 5326-5337.

15. Mills, D.P.; Wooles, A.J.; McMaster, J.; Lewis, W.; Blake, A.J.; Liddle, S.T. Heteroleptic $\left[\mathrm{M}\left(\mathrm{CH}_{2} \mathrm{C}_{6} \mathrm{H}_{5}\right)_{2}(\mathrm{I})(\mathrm{THF})_{3}\right]$ Complexes $(\mathrm{M}=\mathrm{Y}$ or Er): Remarkably Stable Precursors to Yttrium and Erbium T-Shaped Carbenes. Organometallics 2009, 28, 6771-6776.

16. Wooles, A.J.; Mills, D.P.; Lewis, W.; Blake, A.J.; Liddle, S.T. Lanthanide tri-benzyl complexes: structural variations and useful precursors to phosphorus-stabilised lanthanide carbenes. Dalton Trans. 2010, 39, 500-510.

17. Liddle, S.T.; McMaster, J.; Green, J.C.; Arnold, P.L. Synthesis and structural characterisation of an yttrium-alkyl-alkylidene. Chem. Commun. 2008, 1747-1749.

18. Mills, D.P.; Cooper, O.J.; McMaster, J.; Lewis, W.; Liddle, S.T. Synthesis and reactivity of the yttrium-alkyl-carbene complex $\left[\mathrm{Y}(\mathrm{BIPM})\left(\mathrm{CH}_{2} \mathrm{C}_{6} \mathrm{H}_{5}\right)(\mathrm{THF})\right]\left(\mathrm{BIPM}=\left\{\mathrm{C}\left(\mathrm{PPh}_{2} \mathrm{NSiMe}_{3}\right)_{2}\right\}\right)$. Dalton Trans. 2009, 4547-4555.

19. Cotton, S. Lanthanide and Actinide Chemistry; Wiley: Chichester, UK, 2006.

20. Gamer, M.T.; Dehnen, S.; Roesky, P.W. Synthesis and Structure of Yttrium and Lanthanide Bis(phosphinimino)methanides. Organometallics 2001, 20, 4230-4236.

21. Evans, W.J.; Lee, D.S.; Rego, D.B.; Perotti, J.M.; Kozimor, S.A.; Moore, E.K.; Ziller, J.W. Expanding Dinitrogen Reduction Chemistry to Trivalent Lanthanides via the $\mathrm{LnZ}_{3} / \mathrm{Alkali}$ Metal Reduction System: Evaluation of the Generality of Forming $\operatorname{Ln}_{2}\left(\mu-\eta^{2}: \eta^{2}-\mathrm{N}_{2}\right)$ Complexes via $\mathrm{LnZ}_{3} /$ K. J. Am. Chem. Soc. 2004, 126, 14574-14582.

22. Cordero, B.; Gomez, V.; Platero-Prats, A.E.; Reves, M.; Echeverria, J.; Cremades, E.; Barragan, F.; Alvarez, S. Covalent radii revisited. Dalton Trans. 2008, 2832-2838.

23. Shannon, R.D. Revised effective ionic radii and systematic studies of interatomic distances in halides and chalcogenides. Acta Crystallogr. Sect. A 1976, A32, 751-767.

24. Allen, F.H. The Cambridge Structural Database: A quarter of a million crystal structures and rising. Acta Crystallogr. Sect. B 2002, 58, 380-388.

25. Izod, K.; Liddle, S.T.; Clegg, W. A Convenient Route to Lanthanide Triiodide THF Solvates. Crystal Structures of $\mathrm{LnI}_{3}(\mathrm{THF})_{4}[\mathrm{Ln}=\mathrm{Pr}]$ and $\mathrm{LnI}_{3}(\mathrm{THF})_{3.5}[\mathrm{Ln}=\mathrm{Nd}, \mathrm{Gd}, \mathrm{Y}]$. Inorg. Chem. 2004, 43, 214-218.

26. Hill, M.S.; Hitchcock, P.B.; Karagouni, S.M. A. Group 1 and 13 complexes of aryl-substituted bis(phosphinimino)methyls. J. Organomet. Chem. 2004, 689, 722-730.

27. Hill, M.S.; Hitchcock, P.B. Synthesis of a homoleptic Sm(II) bis(phosphinimino)methanide. Dalton Trans. 2003, 4570-4571.

28. Evans, D.F. The determination of the paramagnetic susceptibility of substances in solution by nuclear magnetic resonance. J. Chem. Soc. (Resumed) 1959, 2003-2005. 
29. Vleck, J.H.V. Theory of Electric and Magnetic Susceptibilities; Oxford University Press: Oxford, UK, 1932.

30. Schlosser, M.; Hartmann, J. Transmetalation and Double Metal Exchange: A Convenient Route to Organolithium Compounds of the Benzyl and Allyl Type. Angew. Chem. Int. Ed. Engl. 1973, 12, 508-509.

31. Hitchcock, P.B.; Lappert, M.F.; Maron, L.; Protchenko, A.V.; Lanthanum Does Form Stable Molecular Compounds in the +2 Oxidation State. Angew. Chem. Int. Ed. 2008, 47, 1488-1491.

32. Crystals of $7 \mathbf{b} 3 \mathrm{C}_{7} \mathrm{H}_{8}$ were identified by unit cell check comparisons to La, Pr and Gd analogues.

33. Spek, A.L. Platon, version 1.17; University of Utrecht, Utrecht, The Netherlands, 2000.

34. SMART and SAINT Bruker AXS Inc.: Madison, WI, USA, 2001.

35. CrysAlis PRO; version1.171.35.19; Agilent Technologies: Yarnton, UK, 2010.

36. Sheldrick, G.M. A short history of SHELX. Acta Crystallogr. Sect. A 2008, A64, 112-122.

37. Dolomanov, O.V.; Bourhis, L.J.; Gildea, R.J.; Howard, J.A.K.; Puschmann, H. OLEX2: A complete structure solution, refinement and analysis program. J. Appl. Crystallogr. 2009, 42, $339-341$.

(C) 2013 by the authors; licensee MDPI, Basel, Switzerland. This article is an open access article distributed under the terms and conditions of the Creative Commons Attribution license (http://creativecommons.org/licenses/by/3.0/). 